\title{
Infections associated with immunotherapeutic and molecular targeted agents in hematology and oncology. A position paper by the European Conference on Infections in Leukemia (ECIL)
}

\author{
Georg Maschmeyer $\mathbb{1}^{1}$ - Julien De Greef $\mathbb{D}^{2,3}$. Sibylle C. Mellinghoff ${ }^{4,5} \cdot$ Annamaria Nosari $^{6}$. \\ Anne Thiebaut-Bertrand ${ }^{7} \cdot$ Anne Bergeron $^{8} \cdot$ Tomas Franquet $^{9} \cdot$ Nicole M. A. Blijlevens $^{10}$. \\ Johan A. Maertens ${ }^{11,12}$ on behalf of the European Conference on Infections in Leukemia (ECIL)
}

Received: 19 October 2018 / Revised: 31 December 2018 / Accepted: 11 January 2019 / Published online: 30 January 2019

(c) The Author(s) 2019. This article is published with open access

\begin{abstract}
A multitude of new agents for the treatment of hematologic malignancies has been introduced over the past decade. Hematologists, infectious disease specialists, stem cell transplant experts, pulmonologists and radiologists have met within the framework of the European Conference on Infections in Leukemia (ECIL) to provide a critical state-of-the-art on infectious complications associated with immunotherapeutic and molecular targeted agents used in clinical routine. For brentuximab vedotin, blinatumomab, CTLA4- and PD-1/PD-L1-inhibitors as well as for ibrutinib, idelalisib, HDAC inhibitors, mTOR inhibitors, ruxolitinib, and venetoclax, a detailed review of data available until August 2018 has been conducted, and specific recommendations for prophylaxis, diagnostic and differential diagnostic procedures as well as for clinical management have been developed.
\end{abstract}

a joint venture of the European Group for Blood and Marrow Transplantation (EBMT), the European Organization for Research and Treatment of Cancer (EORTC), the International

Immunocompromised Host Society (ICHS) and the European Leukemia Net (ELN)

Georg Maschmeyer

georg.maschmeyer@klinikumevb.de

1 Department of Hematology, Oncology and Palliative Care, Klinikum Ernst von Bergmann, Charlottenstrasse 72, 14467 Potsdam, Germany

2 Department of Internal Medicine and Infectious Diseases, SaintLuc University Hospital, Université Catholique de Louvain, Brussels, Belgium

3 Assistance Publique-Hôpitaux de Paris (AP-HP), Department of Hematology, Henri Mondor Teaching Hospital, Créteil, France

4 Department I of Internal Medicine, University Hospital of Cologne, Cologne, Germany

5 Cologne Excellence Cluster on Cellular Stress Responses in Aging-Associated Diseases (CECAD), University of Cologne, Cologne, Germany

\section{Introduction}

Immunotherapeutic agents and small molecules for molecular targeted treatment have profoundly changed the landscape of antineoplastic therapy in hematology and oncology. Their impact on innate and adaptive immunity is not yet completely understood. Given to heavily pretreated patients and combined with other anticancer treatment modalities, they may be associated with unexpected,

6 Department of Hematology, ASST Grande Ospedale Metropolitano Niguarda, Milan, Italy

7 Department of Hematology, Université Grenoble Alpes, Grenoble, France

8 Department of Pneumology, Université Paris Diderot, APHP Saint-Louis Hospital, Paris, France

9 Department of Radiology, Hospital de Sant Pau, Barcelona, Spain

10 Department of Hematology, Radboud University Medical Centre, Nijmegen, Netherlands

11 Department of Hematology, University Hospitals Leuven, Leuven, Belgium

12 Department of Microbiology and Immunology, University of Leuven, Leuven, Belgium 
potentially serious infections. However, in heavily pretreated patients, particularly those with chronic lymphocytic leukemia and other indolent B-cell lymphomas, it may be difficult to identify a causal relationship between those infections and drugs administered for lymphoma treatment. As immune-related autoinflammatory reactions are typical adverse events (irAE) occurring in many of these patients, differential diagnostic efforts to distinguish those reactions from infections are crucial. In patients affected by irAE, immunosuppressive treatment will often be required, resulting in secondary infections. This complex scenario calls for a high alertness to formerly unexpected clinical complications among hematologists and oncologists using these newer antineoplastic agents. At the same time, unjustified attribution of infections to these agents and recommendations for routine antimicrobial prophylaxis should be avoided. This position paper updates our current knowledge of infections associated with these agents and provides recommendations for a rational clinical management of prevention and treatment of infections in patients treated with immunotherapeutic and molecular targeted antineoplastic agents.

Immunotherapeutic and molecular targeted antineoplastic agents including checkpoint inhibitors, idelalisib, mTOR inhibitors, and, to a lesser extent, ibrutinib have been associated with drug-related pneumonitis. This pneumonitis is clinically indistinguishable from infectious pneumonias, and the diagnosis relies on the exclusion of differential diagnoses. The specific management of drugrelated pneumonitis includes drug withdrawal and consideration for corticosteroids according to the severity.

\section{Methods}

A group of experts in hematology and oncology, infectious diseases (including virology), pulmonology, diagnostic radiology and hematopoietic stem cell transplantation from six European countries was nominated by the ECIL organization committee in 2016. Immunotherapeutic and molecular targeted agents, which have become available for clinical use within the past decade, including brentuximab vedotin, blinatumomab and immune checkpoint inhibitors as well as HDAC inhibitors, ibrutinib, idelalisib, mTOR inhibitors, ruxolitinib and venetoclax, were addressed. Other agents approved during the last 10 years (such as obinutuzumab, newer proteasome inhibitors, pomalidomide, daratumumab, elotuzumab or inotuzumab ozogamicin) were excluded, because thorough literature searches did not identify relevant infection risks attributable to these agents, or no new signals as compared to older drugs from the same class of agents were found, or because their approval was extremely limited (such as mogamulizumab). A systematic literature review including research papers, case reports, published study results and meta-analyses or review articles was conducted using drug- and class-based search strings: "(agent)" OR "(class)" AND "mode of action" OR "approval" OR "study" OR "infection" OR "infectious" OR "toxicity" OR "adverse events" OR "viral" OR "bacterial" OR "Pneumocystis" OR "fungal" OR "pneumonia" OR "pneumonitis" OR "CNS" OR "hepatitis" OR "cytomegalovirus" OR "immune-related" OR "prophylaxis". The group compiled an extensive slide set including mode of action, state of approval, impact on innate and adaptive immunity, reported infectious complications and recommendations for clinical practice. After mail-based and face-to-face group discussions, the revised and consented slides were presented to the plenary of the seventh ECIL conference in Sophia Antipolis, France, on 22 and 23 September 2017. The plenary decided to abandon grading and strength of recommendations, because the data comprised represent a "moving target" with a rapidly growing body of reports. In order to provide a critical and detailed summary of the current knowledge in the field, the result should be published as an ECIL position paper.

All co-authors have been actively involved in the preparation and discussion of this manuscript.

The agents included are addressed in the following sequence: (1) immunotherapeutic drugs and (2) molecular targeted drugs/drug classes, both in alphabetical order.

A summary of available data as well as ECIL recommendations is listed in Table 1.

\section{Immunotherapeutic agents (blinatumomab, brentuximab vedotin, immune checkpoint inhibitors): characterization, impact on immunity, reported infectious complications and recommendations for clinical practice}

\section{Blinatumomab}

Blinatumomab is a bispecific T-cell engaging (BiTE) antibody, approved for the treatment of Philadelphiachromosome negative relapsed or refractory B-precursor acute lymphoblastic leukemia (R/R ALL) [1]. It is made of a single-chain anti-CD19 antibody attached by a flexible linker peptide to a single-chain anti-CD3 antibody. It induces a close contact between effector T-cells and CD19positive cells, with subsequent T-cell activation and targeted lysis of CD19-positive cells [2]. CD19 is expressed in all $\mathrm{B}$-cell lineage leukemia, and a majority of B-cell lineage lymphomas. In normal cells, it is expressed all along B-cell differentiation, with the exception of pluripotent stem cells and plasma cells [3]. 


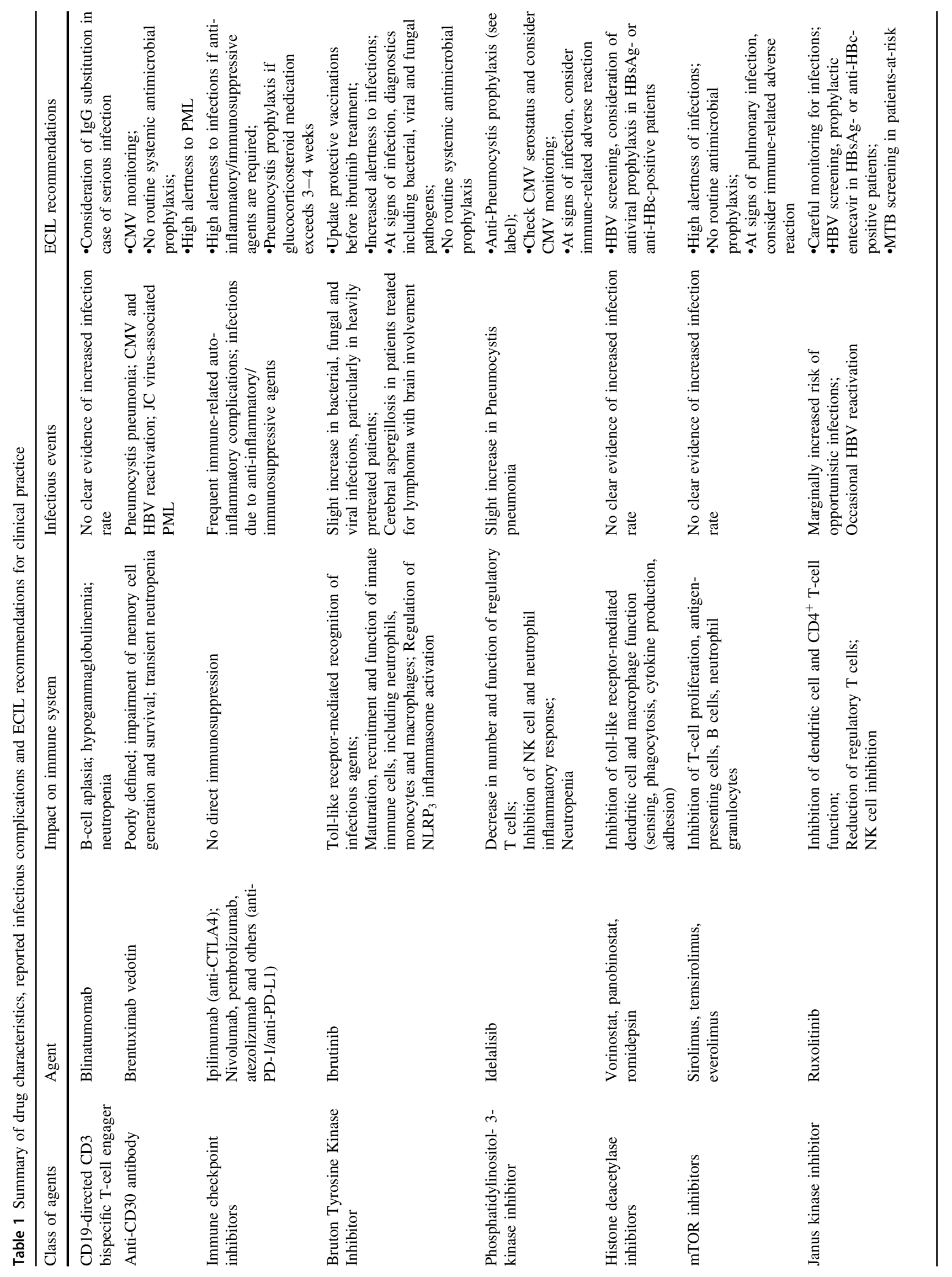




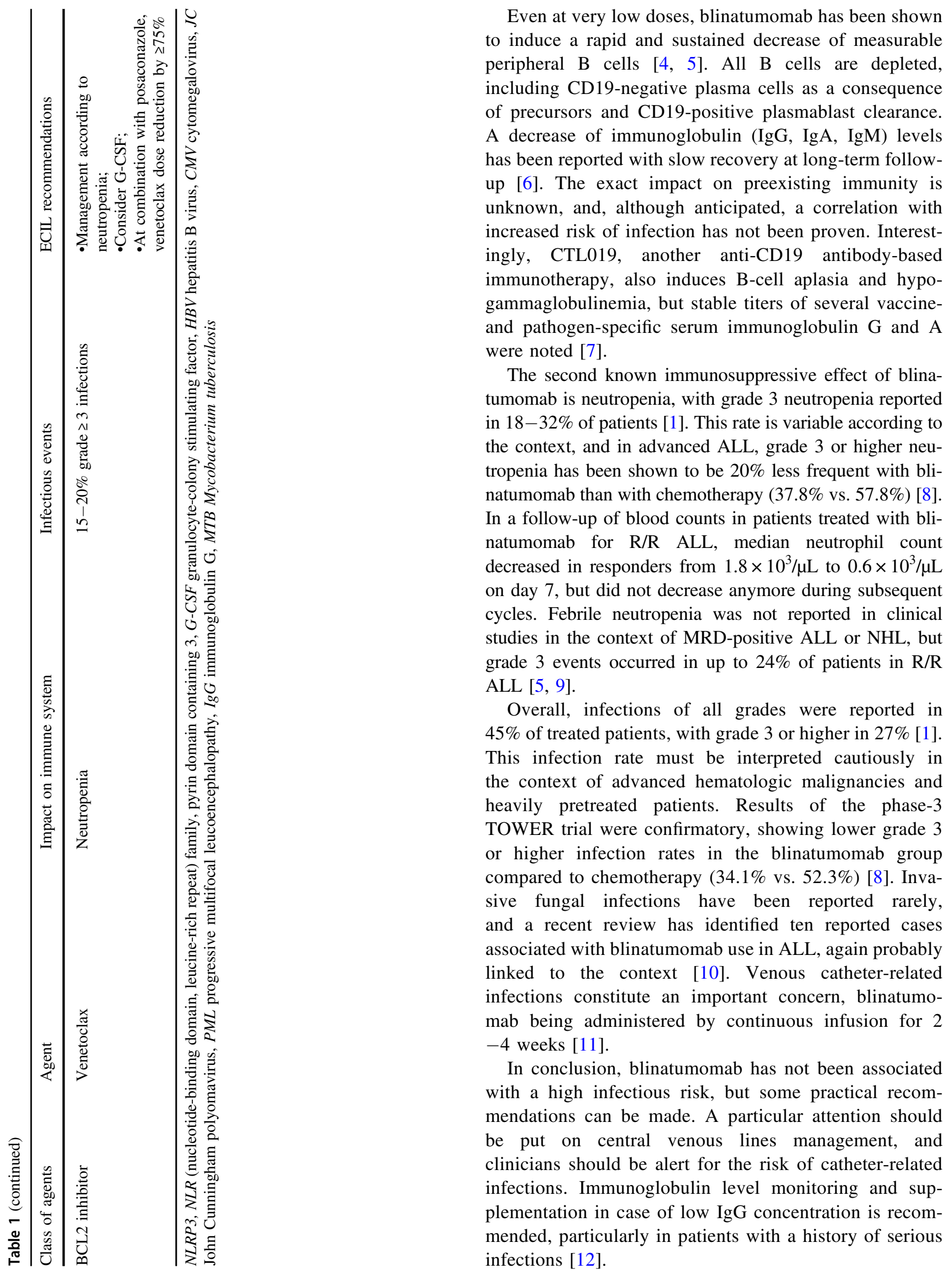

Even at very low doses, blinatumo decrease of measurable peripheral B cells $[4,5]$. All B cells are depleted, including CD19-negative plasma cells as a consequence of precursors and CD19-positive plasmablast clearance. A decrease of immunoglobulin ( $\operatorname{IgG}, \operatorname{Ig} \mathrm{A}, \operatorname{IgM}$ ) levels has been reported with slow recovery at long-term followup [6]. The exact impact on preexisting immunity is unknown, and, although anticipated, a correlation with increased risk of infection has not been proven. Interestingly, CTL019, another anti-CD19 antibody-based immunotherapy, also induces B-cell aplasia and hypogammaglobulinemia, but stable titers of several vaccineand pathogen-specific serum immunoglobulin $G$ and $A$ were noted [7].

The second known immunosuppressive effect of blinaumomab is neutropenia, with grade 3 neutropenia reported in $18-32 \%$ of patients [1]. This rate is variable according to tropenia has been shown to be $20 \%$ less frequent with blinatumomab than with chemotherapy (37.8\% vs. $57.8 \%$ ) [8]. In a follow-up of blood counts in patients treated with blinatumomab for $\mathrm{R} / \mathrm{R}$ ALL, median neutrophil count decreased in responders from $1.8 \times 10^{3} / \mu \mathrm{L}$ to $0.6 \times 10^{3} / \mu \mathrm{L}$ on day 7 , but did not decrease anymore during subsequent cycles. Febrile neutropenia was not reported in clinical studies in the context of MRD-positive ALL or NHL, but grade 3 events occurred in up to $24 \%$ of patients in $R / R$ ALL $[5,9]$.

Overall, infections of all grades were reported in of treated patients, with grade 3 or higher in $27 \%$ [1]. This infection rate must be interpreted cautiously in the context of advanced hematologic malignancies and heavily pretreated patients. Results of the phase-3 TOWER trial were confirmatory, showing lower grade 3 or higher infection rates in the blinatumomab group compared to chemotherapy (34.1\% vs. 52.3\%) [8]. Invasive fungal infections have been reported rarely, and a recent review has identified ten reported cases associated with blinatumomab use in ALL, again probably linked to the context [10]. Venous catheter-related infections constitute an important concern, blinatumomab being administered by continuous infusion for 2 weeks [11]

In conclusion, blinatumomab has not been associated with a high infectious risk, but some practical recommendations can be made. A particular attention should be put on central venous lines management, and clinicians should be alert for the risk of catheter-related infections. Immunoglobulin level monitoring and supplementation in case of low $\operatorname{IgG}$ concentration is recominfections [12]. 


\section{Brentuximab vedotin}

Brentuximab vedotin (BV) is an antibody-drug conjugate (ADC) of a chimeric anti-CD30 antibody and the synthetic anti-tubulin monomethyl auristatin E (MMAE). The ADC binds to the membrane glycoprotein CD30, inducing subsequent intracytosolic release of MMAE after internalization and proteolytic cleavage of the dipeptidic ADC linker [13]. The drug is approved for the treatment of relapsed or refractory CD30-positive classical Hodgkin's lymphoma (HL), as consolidation therapy after autologous hematopoietic stem cell transplantation in HL, and for relapsed or refractory anaplastic large T-cell lymphoma (ALCL) [14].

CD30 is a member of the Tumor Necrosis Factor receptor superfamily, which is highly expressed by ReedSternberg cells in HL and by malignant cells in ALCL. It shows a variable level of expression on the surface of malignant cells in other NHL. CD30 has a low level of expression in normal cells, mainly restricted to a small subset of activated B-, T- (CD4- and CD8-positive) and natural killer (NK) cells [15]. CD30 has been shown to play a complex role in immune response, which has not been fully elucidated yet. Among other, it is thought to help to maintain CD8-positive effector cell activity during antigenic challenge [16]. It is involved in the transition from effector cells to central memory cells and the survival of memory cells. This role in the control of memory cells could help to control pathogens such as listeria and mycobacteria [17]. Other mechanisms have also been suggested implying CD30-positive cells in antimycobacterial immune response, and those cells have been found in positive tuberculin skin tests and TB-infected tissues [18]. By killing CD30-positive cells, BV may induce an immune dysbalance facilitating those infections, but it should be noted that no clinical association has been demonstrated as yet.

Transient dose-dependent neutropenia is a commonly observed side effect of BV. When given as a single agent in relapsed or refractory HL or ALCL or for consolidation therapy after autologous HSCT, BV was shown to induce grade $\geq 3$ neutropenia in $20-29 \%$ of patients. However, febrile neutropenia was extremely rare [19-21]. In contrast, myelosuppression appears to be an important concern when $\mathrm{BV}$ is used in combination with chemotherapy. In a phase 3 study evaluating BV + AVD vs. ABVD in stage III or IV $\mathrm{HL}$, the use of BV was associated with a higher risk of grade $\geq 3$ neutropenia (58\% vs. $45 \%$ respectively) and with higher rates of febrile neutropenia, mainly during the first cycle ( $9 \%$ vs. $4 \%$ respectively). The risk was reduced by primary G-CSF prophylaxis [22].

Overall, BV does not appear to be associated with a high risk of infectious complications. Phase 3 studies did not show a higher infection rate in the $\mathrm{BV}$ group compared to controls [21, 23]. A slightly higher overall infectious risk was described in the BV + AVD group than in the ABVD group, but was mitigated by G-CSF administration [22].

However, some specific concerns have been raised about particular pathogens or situations.

Pneumonia has been reported in up to $10 \%$ of BV-treated patients [14], with even higher rates when combined with chemotherapy [24]. Pneumocystis pneumonia (PcP) was rare $(0.1-1 \%)$ [14]. Noninfectious pulmonary toxicity has been reported [25], but is more likely to be attributable to the coadministration of bleomycin, so that this combination has become contra-indicated [9]. Large phase 3 studies did not show pulmonary toxicity when BV was not combined with bleomycin [21, 23].

Varicella Zoster Virus (VZV) and Herpes Simplex Virus (HSV) infections are described as common side effect of BV, with an incidence of 1-10\% [149]. Extensive or disseminated diseases have been reported [26, 27]; however, a clear causal relationship is doubtful because of the impact of many other risk factors in affected patients.

Although not described in pivotal studies, two case series of cytomegalovirus (CMV) reactivation under $\mathrm{BV}$ have been published, questioning the true incidence of this event and a possible causal relationship. In allogeneic stem cell recipients, $5 \mathrm{CMV}$ viremias among 25 patients treated with $\mathrm{BV}$ for HL recurring after allogeneic HSCT were reported. Three patients required treatment and one died in the setting of CMV reactivation [28]. Another report described three cases of CMV reactivation with retinitis among 32 lymphoma patients treated with BV. Patients responded to therapy, but two out of three relapsed after BV rechallenge [29].

Concerns about a risk of JC virus (John Cunningham polyoma virus) infection in patients treated with $\mathrm{BV}$ have been raised early after the approval of BV. A boxed warning was inserted in the drug label in 2012. At that time, two proven and one probable case of progressive multifocal leukoencephalopathy (PML) had been reported among 2000 patients treated worldwide [30]. Additional cases have been described since then [31], with a total of 15 cases reported until July 2015 to the FDA's Adverse Event Reporting System. The case fatality rate was $33.3 \%$ [32]. It must be kept in mind that those reported cases do not prove a causal relationship, as lymphoid malignancy, multiagent chemotherapy or hematopoietic cell transplantation are PML risk factors [33]. While there is no estimated PML incidence known for patients with HL, the rate for those with NHL is estimated to be 8.3 (95\% CI 1.71-24.24) per 100,000 person-years [34].

For clinical practice, no specific recommendation can be made with regards to antimicrobial prophylaxis. G-CSF prophylaxis should be considered when $\mathrm{BV}$ is used in combination with chemotherapeutic agents. PcP prophylaxis is not required, if $\mathrm{BV}$ is given without concomitant 
treatment [35]. The same rule applies to HSV and VZV prophylaxis [36]. CMV should be taken into consideration in case of symptoms compatible with infection, but no prophylaxis, routine monitoring or preemptive therapy can be recommended for patients undergoing treatment with BV. For JC virus, no prophylaxis is available, but clinicians should be alert and prompt a complete work-up in case of new-onset neurological symptoms suggestive of PML. BV should be withheld until PML has been excluded. In case of confirmation, BV should be discontinued with the aim to restore immunity against JC virus. In some cases this may be complicated by an immune reconstitution inflammatory syndrome [37]. However, in the case of BV-associated PML, due to underlying disease and previous or concurrent treatments, immune recovery is uncertain and the clinical course is unpredictable. PML cases should be notified to local competent authorities, in order to document this rare possible association.

\section{Immune checkpoint inhibitors}

Immune checkpoint inhibition (ICI) has introduced a new era of cancer therapy [38]. It represents a novel therapeutic concept, as the primary target is the crosstalk between immune cells and cancer cells in the tumor microenvironment. Two immune checkpoints are currently targeted by approved drugs: the programmed death 1 (PD-1)/PD-ligand 1 (PD-L1) axis as well as cytotoxic T-lymphocyte antigen-4 (CTLA-4). Blockade of the PD-1 or PD-L1 pathway has been shown to exert therapeutic activity in patients with Hodgkin lymphoma [39], head and neck squamous cell carcinoma [40], advanced melanoma [41, 42], non-small cell lung carcinoma [43, 44], and renal cell carcinoma $[45,46]$. Further indications may follow soon $[47,48]$. The anti-CTLA-4 antibody ipilimumab was the first immunecheckpoint antibody approved for the treatment of patients with advanced melanoma due to its survival benefit compared to standard chemotherapy $[41,49,50]$.

PD-1 is a cell surface coinhibitory receptor expressed on T- and B-lymphocytes, monocytes and NK-cells after activation [51]. To date, PD-L1 (B7-H1) and PD-L2 (B7DC) have been identified as ligands of PD-1. Both ligands are expressed on antigen-presenting cells, and PD-L1 is additionally detected on the surface of various nonhematopoietic cells including tumor cells. The binding of PD-1 to its ligands results in an inhibition of T-cell receptor signaling on activated T-lymphocytes. In addition, the PD-1/PD-L1 pathway is a key component in the development and maintenance of self-tolerance [52]. Furthermore, there is increasing evidence that the PD-1/ PD-L1 pathway is important in the pathogenesis of different tumors by inhibiting, and thus limiting antitumor immune response [53-58].
CTLA-4 is a second immune-checkpoint expressed during priming of $\mathrm{T}$ cells [41].

Inhibition of the PD-1/PD-L1 as well as the CTLA-4 pathway non-specifically activates the immune system resulting in imbalance. A broad spectrum of immune-related adverse events (irAE) may occur, involving the gut, skin, endocrine glands, liver, lungs [59], and possibly other organs $[60,61]$. One rare irAE is neutropenia caused by autoantibodies against neutrophils. Two cases have been reported, one of them associated with a Staphylococcus aureus infection [62, 63]. IrAE often require immunosuppressive medication, which in turn increases the susceptibility to severe infections $[47,64,65]$, resulting in up to $7.3 \%$ opportunistic infections in patients affected [66]. Few data (mostly preclinical) report on higher risk for tuberculosis [67], histoplasmosis [68], and listeriosis [69, 70] due to ICI. At present, the incidence of infection is undetermined and the role of prophylactic antiviral and antifungal therapy in this setting is undefined.

Prophylaxis of $\mathrm{PcP}$ should be considered if secondary immunosuppression is given for at least 3 weeks $[35,71,72]$ As patients receiving ICI are at increased risk of infection due to their underlying malignancy, it is recommended that they receive all appropriate vaccines at the earliest possible moment [73]. Future identification of biomarkers predicting $\mathrm{AE}$, e.g. microbiota in the gut, may help to facilitate preemptive treatment $[74,75]$.

\section{Molecular targeted agents (ibrutinib, idelalisib, HDAC inhibitors, mTOR inhibitors, ruxolitinib, venetoclax): characterization, impact on immunity, reported infectious complications and recommendations for clinical practice}

\section{Ibrutinib}

The inhibition of Bruton's tyrosine kinase (BTK) is a crucial strategy for treating B-cell malignancies. Ibrutinib, an irreversible inhibitor of BTK, is now approved for the treatment of chronic lymphocytic leukemia (B-CLL) [76, 77], mantle cell lymphoma [78], marginal zone lymphoma [79], small lymphocytic lymphoma [80] and Waldenström's macroglobulinemia [81]. Ibrutinib is also the first approved therapy for the treatment of chronic graftversus-host disease after failure of one or more lines of systemic therapy [82]. BTK has been widely characterized as a critical mediator of B-cell receptor signaling that regulates B-cell survival, activation, differentiation, and interaction with the environment [83]. Germline mutations in the gene encoding for BTK result in an almost complete absence of mature B cells and hypogammaglobulinemia, the 
hallmark of X-linked (Bruton's) agammaglobulinemia [84]. Hence, BTK is essential in the development and functioning of adaptive immunity. However, BTK also plays a major role in innate immunity: (a) in Toll-like receptor-mediated recognition of infectious agents, (b) in maturation, recruitment and function of innate immune cells, including neutrophils, monocytes and macrophages, and (c) in regulating $\mathrm{NLRP}_{3}$ inflammasome activation [85]. Thus, targeting BTK with ibrutinib in a population already characterized by an immune dysregulation (e.g. CLL) will most likely result in an increased risk of infection.

Collectively, the randomized pivotal trials demonstrate that upper respiratory tract infections are the most common infectious complications in ibrutinib-treated patients, albeit mostly self-resolving [76-81]. Pneumonia is the most common serious infectious event. The frequency and pattern of infections appears to reflect what is typically seen in this B-cell malignancy population, rather than a drugspecific adverse event profile. Infectious complications are considerably fewer and less severe in treatment-naïve (TN) compared with relapsed/refractory (R/R) patients, i.e., $13 \%$ vs. $51 \% \geq$ grade 3 infections: pneumonia (6\% vs. $25 \%$ ), sepsis $(0 \%$ vs. $7 \%)$, cellulitis ( $0 \%$ vs. $5 \%)$ sinusitis $(0 \%$ vs. $5 \%)$ and bacteremia (0\% vs. 4\%) [86]. The infectious morbidity appears to decrease over time; grade $\geq 3$ infections are observed more frequently during the first 6 months of therapy, often during the first $2-3$ months. This trend is related to the extended time from last chemotherapy in $R / R$ cases, early response and disease control, and the immunomodulating potential of ibrutinib. In addition, prolonged ibrutinib treatment results in a partial reconstitution of the humoral immunity with stabilization or improvement of immunoglobulin levels and of the normal B-cell populations [87].

Not unexpectedly in these often heavily pretreated patients, opportunistic infections have been sporadically reported, including cases of cryptococcal disease (meningoencephalitis/disseminated disease) [88-91], (miliary) tuberculosis [92, 93], endemic mycosis, PML (in rituximab pretreated patients) caused by JC virus [94-96], Epstein - Barr Virus (EBV)-driven hemophagocytic syndrome [97], and reactivations of Hepatitis B virus (HBV) [98, 99].

Following a report of five cases of PcP in a cohort of 96 patients [100], concern has risen that ibrutinib therapy could increase the risk of $\mathrm{PcP}$, although no other study has reported a frequency above $1 \%$. These PcP cases occurred in previously untreated CLL patients receiving ibrutinib monotherapy and presented in a "nontypical" way [100]: (a) patients were asymptomatic or had only mild, often chronic respiratory symptoms; (b) there was no long-term use of steroids or other immunosuppressive drugs; (c) chest computed tomography scan revealed nontypical multifocal nodular infiltrates; (d) $\mathrm{CD} 4^{+} \mathrm{T}$-cell counts were high $(>500$ per microliter), (e) and no patient required intravenous therapy, adjunctive steroid treatment or mechanical ventilation. Of note, only one of these five cases was confirmed by immunofluorescence, still considered the gold diagnostic standard for PcP. The FDA Division of Pharmacovigilance recently reviewed 13 additional cases of confirmed and presumed PcP submitted to the FDA Adverse Event Reporting System [101]. Contrary to the previous case series, ten of these cases had refractory underlying disease with prior exposure to other immunosuppressive agents and six cases reported concomitant use of such agents. Thus, although the inhibitory effect of ibrutinib on interleukin-2-inducible kinase makes an increased risk for $\mathrm{PcP}$ biologically plausible, $\mathrm{PcP}$ prophylaxis is not routinely recommended; its risk-benefit should be outweighed in the context of diminished T-cell immunity due to previous (e.g. fludarabine-cyclophosphamide-rituximab therapy) or concomitant therapy [35].

Among thousands of patients with a variety of B-cell malignancies treated with ibrutinib, invasive mold infections have been reported only sporadically. The frequency of invasive yeast and mold infections in the clinical studies was low, ranging from 0 to $3.2 \%$ [1-6]. More recently, a retrospective French survey reported 27 cases of invasive aspergillosis from 16 centers [102]. Most cases occurred early-on within a median of 3 months after starting ibrutinib for relapsed/refractory disease. Cerebral involvement was frequent $(40 \%)$. Unfortunately, the survey did not report a denominator, and the majority of patients had at least one additional factor, aside from hypogammaglobulinemia, that increased their risk for fungal infections [102]. During a 5-year period (2012-2016), invasive fungal infection (including pulmonary and disseminated aspergillosis, pulmonary cryptococcosis, and $\mathrm{PcP}$ ) developed in $4.2 \%$ of ibrutinib-treated patients at the Memorial Sloan Kettering Cancer Center [103]. Experimental use of single-agent ibrutinib in patients with primary central nervous system lymphoma was associated with a 5-27\% frequency of invasive aspergillosis, including cerebral disease [104, 105]. Clearly BTK plays a role in innate fungal immune surveillance (as demonstrated in $B t k^{-1-}$ mice studies [104]) via a series of mechanisms mentioned before [85]. Obviously ibrutinib impairs that fungal immune surveillance, thereby contributing to the complex "net state of immunosuppression", although the increased susceptibility to fungal disease in ibrutinib-treated patients remains primarily dictated by the status of the underlying lymphoid malignancy, the combined action with other immunosuppressive therapies and the environmental exposure to fungal pathogens $[103,106]$. However, these reports underscore the need for heightened awareness and vigilance to identify any change in fungal epidemiology in view of the rapidly growing availability of novel therapeutic agents with 
immunosuppressive characteristics. Pending further epidemiological data, routine mold-active prophylaxis is currently not recommended (outside the setting of severe graft-versus-host disease post-allogeneic stem cell transplantation, where ibrutinib may become a treatment option). It must be kept in mind that mold-active azoles interfere with ibrutinib elimination by inhibiting the CYP3A4 enzyme system, potentially increasing the risk of adverse events [107]. However, as the indications for ibrutinib use continue to expand, better identification of risk factors for invasive fungal disease may define populations in which monitoring and antifungal prophylaxis can be studied as potential preventive strategies [103].

Guidelines recommend vaccination against influenza and pneumococcal disease in patients with B-cell malignancies [73, 108]. However, recent prospective data demonstrate that ibrutinib may dramatically impair adequate serological responses to vaccination [109, 110]; hence, clinicians may consider vaccinating patients before the initiation of antineoplastic therapy.

Finally, there have been sporadic reports of pneumonitis in patients receiving ibrutinib [111]. These cases present early (1-4 months) after initiation of therapy and are clinically indistinguishable from infectious complications (e.g. PcP or viral pneumonitis). Diagnosis is established by ruling out other differential diagnoses; treatment includes ibrutinib withdrawal and corticosteroids.

\section{Idelalisib}

Idelalisib is a selective inhibitor of adenosine-5'-triphosphate in the phosphatidylinositol-3-kinase delta (PI3K 8 ). It is approved since 2014 in combination with rituximab for the treatment of relapsed chronic lymphocytic leukemia (B-CLL) and for first-line therapy of B-CLL with del17p or TP53 mutation and as a monotherapy for refractory follicular lymphoma.

Phosphatidylinositol 3-kinase (PI3K) comprises a group of related lipid enzymes regulating pleiotropic downstream effector functions. Class I PI3Ks are heterodimers of regulatory and catalytic subunits with four different isoforms, $\alpha, \beta, \gamma$ and $\delta$, involved in cell proliferation, survival, and motility $[112,113]$. The $\alpha$ and $\beta$ isoforms are widely expressed in many tissues, whereas $\gamma$ and $\delta$ isoforms are restricted to hematopoietic cells. In B lymphocytes, the $\delta$ isoform (PI3K $\delta$ ) plays a central role in normal B-cell development and function, transducing signals from B-cell receptor as well as from receptors for various cytokines, chemokines and integrins [114, 115]. PI3K $\delta$ signaling pathways are frequently hyperactive in many B-cell malignancies [116-118], so that the inhibition of $\delta$ isoform-specific PI3K signaling is a promising approach for the therapy of B-cell lymphoma. Idelalisib blocks PI3K 8 -
AKT (protein kinase B) signaling and promotes apoptosis of B-lymphocytes.

Few reports describe a higher risk of opportunistic infections in patients treated with idelalisib, particularly PcP and CMV infections, even in the setting of normal neutrophil counts and absence of profound lymphocytopenia. It was hypothesized that PI3K inhibitors cause an increased susceptibility to infections through impairment of granulocyte activation [119]. Four trials have been published on monotherapy [120-123], three in combination with anti CD20 [124-126] and four with other combinations [127-130]; three of them were stopped early because of excess adverse event rates (hepatotoxicity and pneumonitis) [128-130].

Regarding bacterial infections, no increased risk was found to be associated with idelalisib. For clinical practice, no specific recommendations for antibacterial prophylaxis can be given. Sehn et al. published a retrospective analysis of 2198 patients receiving idelalisib alone or in combination with co-therapy (anti-CD20 antibody or bendamustine + rituximab) and patients receiving only co-therapy (antiCD20 \pm bendamustine) [131]. The overall incidence of PcP was $2.5 \%$ in patients on idelalisib \pm co-therapy vs. $0.2 \%$ in patients receiving anti-CD20 antibody alone or in combination with bendamustine (relative risk, 12.5). A correlation between CD4 counts (e.g., $<200$ cells/ $\mu \mathrm{L}$ ) and an increased risk of $\mathrm{PcP}$ was not observed. Only $1.2 \%$ of patients receiving anti-Pneumocystis prophylaxis developed this complication, as compared to $3.5 \%$ of those without prophylaxis, and among the $20 \%$ of patients in whom PcP prophylaxis was administered, no deaths occurred. Thus, there is a small, but increased risk of PcP during treatment with idelalisib. Prophylaxis with trimethoprimsulfamethoxazole is included in the label now, and the European Society of Clinical Microbiology and Infectious Diseases study group for infections in compromised hosts (ESGICH) suggests PcP prophylaxis during idelalisib therapy and for 2-6 months after its discontinuation [132]. From our perspective, PcP prophylaxis is recommended, but based on weak evidence [133, 134].

Cytomegalovirus reactivations are notified in randomized trials for 52 of 2204 patients $(2.4 \%)$ treated with idelalisib (https://www.ema.europa.eu/documents/variation-report/ zydelig-h-c-003843-a20-1439-0023-epar-assessmentreport-article-20_en.pdf) $[123,126,127,135]$. The incidence rate is higher when idelalisib is combined with bendamustine (13/207 patients; 6.3\%) (https://www.ema. europa.eu/documents/variation-report/zydelig-h-c-003843-a 20-1439-0023-epar-assessment-report-article-20_en.pdf)

[127, 135]. CMV serostatus must be defined for all patients before treatment initiation. For CMV-negative patients, CMV-negative or filtered blood products are recommended and CMV antigen or PCR should be checked at least every 
4 weeks. In case of positive PCR/antigen with increasing viral load or symptoms consistent with CMV disease, ganciclovir or valganciclovir treatment is recommended and idelalisib should be discontinued [134].

\section{Histone deacetylase (HDAC) inhibitors (panobinostat, vorinostat, romidepsin)}

HDAC inhibitors are used for epigenetic treatment affecting the coiling and uncoiling of DNA around histones, involving histone acetyl transferases and histone deactetylases [136]. For use in clinical hematology, panobinostat (in combination with bortezomib and dexamethasone for recurrent multiple myeloma), vorinostat (T-cell lymphoma progressive, persistent or recurrent on or following two systemic therapies) and romidepsin (treatment of relapsed cutaneous T-cell lymphoma and peripheral T-cell lymphoma) are approved.

HDAC inhibitors exert a plethora of inhibitory effects on innate immunity, in particular on toll-like receptor-mediated dendritic cell (DC) and macrophage function such as sensing, phagocytosis, cytokine production or adhesion [137], resulting in increased microbial susceptibility and reduced inflammatory response [138]. However, in controlled clinical trials on HDAC inhibitor use in patients with multiple myeloma, malignant lymphoma (T cell, B cell or Hodgkin's), acute myeloid or lymphoblastic leukemia or myelodysplastic syndrome, no significant increase in infection rates or fever have been observed in comparison with control groups [139-150]. A notable rate of asymptomatic interstitial pneumonitis has been reported from a clinical trial on panobinostat used for treatment of Waldenström's Macroglobulinemia [151]. From observations outside clinical hematology, a potential use of HDAC inhibitors for improved clearance of Human Immunodeficiency Virus has been postulated [152-155].

For clinical practice, no clear evidence of HDAC inhibitor-attributable increase in the risk of infection or infection-related mortality has been reported. Hence, there is no rationale for specific prophylaxis and for specific diagnostic procedures in case of fever in hematologic patients under treatment with HDAC inhibitors. Considering their negative impact on inflammatory response, screening for HBV and consideration of prophylactic drug treatment in case of reactivation risk may be recommended. In patients with active infection, HDAC inhibitor treatment should be withheld. In case of cough and/or dyspnea, drugrelated interstitial lung disease should be taken into consideration. HDAC inhibitor use in HIV-positive patients with hematologic malignancies does not seem to increase the risk of HIV activation.

\section{mTOR inhibitors (sirolimus, temsirolimus, everolimus)}

Inhibitors of the mammalian target of rapamycin (mTOR) are approved for immunosuppression post solid organ transplantation and the treatment of mantle cell lymphoma, breast cancer, neuroendocrine tumors and renal cell cancer. Sirolimus, temsirolimus and everolimus are available for clinical application.

mTOR is acting as a serine/threonine protein kinase in the PI3k/AKT signaling pathway of growth factor receptors such as epidermal growth factor (including HER-2), vascular endothelial growth factor and insulin-like growth factor-1 receptor. Immunosuppression and impaired wound healing may result from inhibition of T-cell proliferation, antigen-presenting cells, B cells, neutrophil granulocytes, mast cells and stromal cells [156, 157]. A meta-analysis of published reports on 5436 patients treated with mTOR inhibitors showed a nonsignificantly increased risk of allgrade leukopenia and neutropenia [158], while another meta-analysis of 3180 mTOR inhibitor-treated patients [159] demonstrated a relative risk of all-grade and highgrade infections of $2.00(95 \% \mathrm{CI}, 1.76-2.28, p<0.001)$ and 2.60 (95\% CI, 1.54-4.41, $p<0.001$ ), respectively, as compared with patients in the control arms of the studies. Infections mainly affect the respiratory tract (61.7\%), genitourinary tract $(29.4 \%)$ and skin/soft tissue $(4.2 \%)$. A difference in incidences or risks between everolimus and temsirolimus or between different tumor types (renal cell carcinoma vs. others) was not observed. Among respiratory tract infections, no increase in the risk of specific types of pneumonia such as $\mathrm{PcP}$, invasive mold or CMV infection was found to be associated with mTOR inhibition [160]. Urinary tract infections caused by polyomavirus or CMV were even less frequently observed in 4930 renal transplant recipients receiving mTOR inhibitors as compared with those treated with mycophenolate for preventing graft rejection [161]. A meta-analysis of 14 clinical trials on post-transplant mTOR inhibitor treatment confirmed a lower rate of CMV reactivation among heart transplant recipients [162].

Studies conducted in patients with metastatic cancers (renal, breast or lung) reported mTOR inhibitor-related pneumonitis with a large variation in incidence [163-165].

For clinical practice, no specific recommendations for antimicrobial prophylaxis or for the diagnostic approach to individual patients with fever emerging under treatment with mTOR inhibitors can be given. In light of their overall increased risk of infectious complications, a high level of alertness is required. In patients who develop cough and/or dyspnea, drug-related interstitial lung disease should be taken into consideration. 


\section{Ruxolitinib}

Ruxolitinib is an inhibitor of Janus kinases (JAKs), which are non-receptor tyrosine kinases mediating signal transduction induced by cytokines. JAK2 $2^{\mathrm{V} 617 \mathrm{~F}}$ mutation results in constitutive activation of the JAK/STAT (signal transducer and activator of transcription) signaling pathway. Ruxolitinib alleviates constitutional symptoms of myelofibrosis (MF) by downregulating interleukin (IL)-1b, IL-6 and TNF- $\alpha$. Ruxolitinib was approved for treatment of advanced MF and Polycythaemia Vera (PV).

Until now, three possible mechanisms of ruxolitinib immunomodulatory effects and immunosuppressive action have been identified, mainly based on dendritic, T- and natural killer (NK) cells. The first mechanism is the ruxolitinib-induced effect on DCs differentiation and function in vitro and in vivo blocking DC development [166]. In the presence of ruxolitinib, the cells morphologically and phenotypically resemble monocytes rather than DCs, and IL -12 cytokine production, which is critical for naive CD8-positive T-cell activation to acquire cytotoxic activity and to destroy infected or transformed cells, is markedly reduced. Finally, proper DC migration to secondary lymphoid organs, in order to induce T-cell responses, is also severely reduced [167].

The second mechanism involves T-cells. JAK/STATsignaling is involved in the regulation of CD4-positive $\mathrm{T}$ cells, which mediate inflammatory responses and protect against a wide range of pathogens by adopting a series of distinct differentiated states, i.e., $\mathrm{T}$ helper cell type 1 (Th1), Th2, Th17, regulatory $T$ cells $\left(T_{\text {regs }}\right)$, etc. Ruxolitinib treatment significantly inhibits CD4+ T-cell activation and differentiation $[168,169]$ reducing the number of proinflammatory Th1, Th17 and $\mathrm{T}_{\text {regs }}$, that have also a protective role against specific viral pathogens (e.g., HSV 2, lymphocytic choriomeningitis virus, West Nile virus), some parasites (Plasmodium spp., Toxoplasma gondii) and fungal pathogens (Candida albicans) [170].

The third immunosuppressive mechanism involves NK cells probably because cytokine signals mediated via the JAK/STAT pathway are determinant for NK cell activation and maturation. In ruxolitinib-treated patients, NK cell numbers are drastically reduced, in part due to defective NK cell terminal maturation [171, 172], explaining the time-dependent decrease of NK cell numbers during ruxolitinib intake. Ruxolitinib therapy is associated with the reactivation of HSV and VZV infections, similar to patients with an inherited functional NK cell deficiency [172].

Infections are among the main causes of morbidity and mortality in MF, representing the cause of death in around $10 \%$ of the cases $[173,174]$, mainly in advanced stages of disease.
The randomized COMFORT-I study [175] comprised 309 patients with splenomegaly and intermediate- 2 or highrisk IPSS who are probably more sensitive to infections due to more advanced disease. Bacterial infections and in particular urinary tract infections (9\%) and VZV (1.9\%) were the main infections that occurred in patients receiving ruxolitinib during randomized treatment. At 5-years followup [176], the most severe infections were pneumonia and sepsis at similar rates in patients treated with ruxolitinib or placebo. Over time, VZV infections occurred at higher rate in patients treated with ruxolitinib compared to placebo, but the majority of cases were single episodes grade 1 or 2 . After 36 months, no other opportunistic infections occurred. Similar results were obtained in the COMFORT-II trial [177], in which ruxolitinib was compared with the best available therapy in 219 patients. Pneumonia was the only serious infectious adverse event reported (1\% in the ruxolitinib group vs. $5 \%$ in the "best available therapy" group). The other infections were of grade 1-2. In the 5-year final analysis [178], with a median duration of exposure to ruxolitinib of 2.6 years, VZV infections (11.5\%), pneumonia (13\%), sepsis $(7.9 \%)$ and urinary tract infections (24.6\%) were found; however, grade 3 or 4 urinary tract infection was reported only in $1.0 \%$ of patients, VZV in $4.3 \%$, and no trends towards an increase in the rate of sepsis were seen over time. Two cases $(1 \%)$ of tuberculosis (TB) were also documented.

Other studies confirmed the predominance of bacterial and viral infections besides sporadic opportunistic infections. The ROBUST trial [179], including 48 patients with intermediate- 1 and -2 and high risk, showed only bacterial infections (urinary tract infections $16.7 \%$, respiratory tract infections $25 \%$ ) or unexplained fever (12.5\%), except one case of PML. There were no reports of VZV, HBV or TB. In the JUMP expanded-access trial [180], 1144 intermediate and high-risk MF patients without access to ruxolitinib outside of a clinical study were included. All-grade infections were mainly bacterial and viral and similar to those present in the registry studies. TB was seen in three patients $(0.3 \%)$ and Legionella pneumonia in one patient $(0.1 \%)$; no HBV reactivation was reported. Among patients with resistant PV and JAK2 mutation included in the RESPONSE-1 trial [181], the rate of grade 3 or 4 infections at week 32 was $3.6 \%$ and $2.7 \%$, respectively, similar in both ruxolitinib-treated patients and the control group treated with the best available therapy; VZV infections, all of grade 1 or 2 , occurred in seven patients in the ruxolitinib group (6.4\%) as compared with no patients receiving standard therapy. Similar results were obtained from the randomized study RESPONSE-2 [182] assessing 149 phlebotomydependent patients resistant or intolerant to hydroxyurea, 74 in the ruxolitinib group versus 75 in the "best available therapy" group. Among all patients, grade 3 infections were 
rare (two cases in the ruxolitinib group; influenza and bronchitis) and one case (influenza) in the control group. No pneumonia or TB reactivation was diagnosed in the ruxolitinib group. Thus, ruxolitinib was not an independent risk factor for infections in this study.

A recent retrospective analysis of 507 MF patients, diagnosed between 1980 and 2014 in five Italian hematology centers [183], described the epidemiology of infections and the impact of ruxolitinib treatment in MF. One hundred and twelve patients (22\%) experienced 160 infectious events (grade 3-4, 45\%), more frequent in IPSS intermediate- 2 and high-risk patients and in those carrying an unfavorable karyotype. The infections were mainly bacterial $(78 \%)$, viral $(11 \%$, more frequent in IPSS intermediate-2/high-risk patients) and fungal (2\%); also three cases of TB infection $(0.5 \%)$ were diagnosed. The frequency of infections was significantly higher among the 128 patients treated with ruxolitinib (cumulative incidence rate of $6.1 \%$ vs. 3.9 per patient-year). The type and site of infections were similar to those observed in the general population, but in ruxolitinib-treated patients, the rate of infections $(44 \%$ vs. $20 \%, p<0.001)$ was higher compared to ruxolitinib-untreated patients, probably also because these patients were at IPSS intermediate-2/high-risk and most $(61.7 \%)$ carried a large splenomegaly, the two leading risk factors identified for infections by multivariate analysis in this study. Overall, infections were fatal in $9 \%$ of the cases. Finally, in 70 patients with MF at lower risk (intermediate-1) treated with ruxolitinib [184], after a median time of 8 months from the start of ruxolitinib, infectious complications >grade 2 were $15.9 \%$, and were mainly bacterial (with one bone TB infection) and viral infections.

Overall, these data confirm the predominance of bacterial infections, in particular in the first months of treatment (decreasing along treatment exposition) as well as in patients who did not respond to ruxolitinib, while the VZV infection rate increased over time up to $10-11 \%$; infections were mostly of grade $1-2$. Some authors propose that prophylaxis with antiviral drugs could be considered in case of previous history of Herpes virus disease. Moreover, the immunosuppressive effects of ruxolitinib may have played a role in isolated cases of serious opportunistic infections [185-196], such as PML [77], toxoplasmosis [186], CMV [187], cryptococcosis [188-190], PcP and other fungal infections [191-193], EBV [194, 195], VZV meningoencephalitis [196] and, more frequently, reactivation of HBV and TB.

The widespread use of molecularly targeted drugs with immunosuppressive or immunomodulating action has increased the risk of HBV reactivation, which may clinically vary from an asymptomatic replication to severe hepatitis and even fatal hepatic failure. The actual incidence of $\mathrm{HBV}$ reactivation following ruxolitinib therapy is unknown, because most clinical trials excluded the enrollment of patients with active HBV. Until now, five case reports are described in the literature [197-200], highlighting the importance of close monitoring of liver function tests and plasma HBV-DNA level in HBV carriers receiving ruxolitinib therapy. Recently published guidelines [201] recommend $\mathrm{HBV}$-screening for hematologic patients scheduled for chemotherapy and/or immunotherapy for both HBV reactivation and HBV risk factors as the first step in preventing reactivation. Screening should include HBsAg, anti-HBc and anti-HBs, and HBV-DNA if anti$\mathrm{HBc}$ is positive. $\mathrm{HBV}$-seropositive individuals should be started on antivirals in a timely manner. Recent guidelines $[36,202,203]$ recommend the use of antiviral drugs with a higher barrier to resistance rather than lamivudine for firstline treatment. Entecavir and tenofovir are now preferred because of their lower viral resistance rates. The Centers for Disease Control and Prevention (CDC) have recommended routine postvaccination tests for anti-HBs and annual booster doses for sustained immunity among high-risk groups and immunocompromised individuals. Careful assessment of $\mathrm{HBV}$ infection is required before starting ruxolitinib, and monitoring of HBV markers and prophylaxis might be required for any patients that demonstrate an HBV infection during the treatment course [204].

The notification of TB cases in registry data $[177,178]$ and other studies [180, 183, 184] as well as case reports [205-213] have suggested a causative role of ruxolitinib in the emergence of tuberculosis. Before ruxolitinib treatment, an accurate TB history should be always taken, and the screening for latent TB must be considered if epidemiological risk factors are significant (history, endemic areas, trips in endemic areas) with Tuberculin Skin Test (TST) or (preferably) IFN- $\gamma$ Release Assay, IGRA (i.e. QuantiFERON test) [204, 208]. After commencing ruxolitinib, regular follow-up of patients is advised, especially for the first 6 months, to assess for the development of opportunistic infections and TB reactivation. In the TB case reports, anti-infectious treatment was effective in most patients and, if clinically indicated, ruxolitinib was successfully resumed [207, 208] after infection eradication, resulting in MF improvement with no TB relapse.

In conclusion, ruxolitinib-treated patients should be carefully evaluated for serious infections at the onset of fever. Age and comorbidities, treatment modalities (such as glucocorticosteroids), IPSS score [214] and environmental exposure may further influence the risk of infections. Main reported infections are bacterial, in particular urinary tract infections, pneumonia, sepsis, and viral, in particular VZV infection and influenza, but ruxolitinib was also associated with a potentially increased risk of opportunistic infections. As reported in a recent meta-analysis regarding ruxolitinibassociated infections [215], severe infections may delay the 
eligibility of MF patients to allogeneic transplantation, so a careful evaluation of the risk of infections is recommended before ruxolitinib treatment.

HBV reactivation was occasionally seen in patients with previous history of hepatitis and/or with occult infection. Before ruxolitinib treatment, HBV screening in all patients and prophylaxis preferably with entecavir in patients HBsAg-positive and/or anti-HBc-positive is recommended. Screening for latent TB should be considered if epidemiological risk factors and medical history are significant.

In case of fever after ruxolitinib discontinuation, the possibility of a rare "ruxolitinib withdrawal syndrome", a syndrome presenting respiratory distress, progression of splenomegaly, fever or pruritus, mimicking an infection, should be considered [216, 217].

\section{Venetoclax}

Venetoclax is a potent and specific inhibitor of the antiapoptotic BCL-2 protein. It has been approved for the treatment of B-CLL (as third-line therapy or as second-line therapy in case of $17 \mathrm{p}$ deletion or TP53 mutation), where it has been shown to induce a rapid apoptosis of CLL cells, known to be BCL-2 dependent [218].

The only immunosuppressive effect associated with venetoclax is related to cytopenias. High-grade neutropenia in particular has been shown to be a common adverse effect in phase I and II studies in CLL [219, 220].

The relative role of venetoclax in this setting has been questioned, as pretreatments and marrow infiltration by CLL may have a substantial impact. Neutropenia occurs mainly during the first 3 months of treatment, and an inverse correlation has been shown between blood venetoclax concentration and risk of neutropenia and infection [221]. Improvement may therefore be related to bone marrow clearance from B-CLL. However, the causal role of venetoclax is highly probable. Venetoclax has been shown to suppress granulopoiesis in vitro and in animal models [222]. Moreover, comparative data from a phase 3 trial comparing rituximab-venetoclax to rituximab-bendamustin in relapsed or refractory CLL have shown a higher rate of grade 3 or 4 neutropenia in the venetoclax group $(57.7 \%$ vs. $38.8 \%$ ) [223]. Interestingly, cyclic administration of venetoclax (1 week on therapy, 3 weeks off) was not associated with neutropenia in a study on venetoclax use in systemic lupus erythematosus [224].

The real risk of infections associated with venetoclax in patients with B-CLL is unknown. In an aggregated safety analysis including one phase 1 and two phase 2 studies of venetoclax monotherapy in relapsed or refractory B-CLL, the drug has shown a manageable safety profile. Grade 3 or higher overall infection rate was 19\% [225]. Reassuringly, although neutropenia was more frequent, a lower rate of grade 3 or 4 febrile neutropenia (3.6\% vs. 9.6\%) and grade 3 or 4 infections ( $17.5 \%$ vs. $21.8 \%$ ) was reported with rituximab-venetoclax in comparison to rituximab-bendamustin [223].

Neutropenia has usually been managed with dose reduction or transient interruption, and G-CSF has been used with good response [220, 226]. According to the manufacturer, treatment should be withheld in case of grade 4 hematologic toxicity or in case of grade 3 or 4 neutropenia with infection or fever [227]. Infection without neutropenia has seldom led to venetoclax interruption or dose reduction [220].

Venetoclax is a substrate of CYP3A, raising concerns about the impact of CYP3A inducers or inhibitors, such as azole antifungal agents. The impact of posaconazole coadministration has been well studied, and venetoclax dose should be reduced by at least $75 \%$ [228].

Acknowledgements The authors would like to thank the meeting participants of ECIL 7, Sophia Antipolis, France, 22 and 23 September 2017: Murat Akova, Ankara, Turkey; Mahmoud Aljurf, Riyadh, Saudi Arabia; Diana Averbuch, Jerusalem, Israel; Anne Bergeron, Paris, France; Nicole Blijlevens, Nijmegen, Netherlands; Aida Botelho de Sousa, Lisbon, Portugal; Alessandro Busca, Turin, Italy; Thierry Calandra, Lausanne, Switzerland; Simone Cesaro, Verona, Italy; Catherine Cordonnier, Créteil, France; Roberto Crocchiolo, Milan, Italy; Julien De Greef, Brussels, Belgium; Rafael de la Camara, Madrid, Spain; Hugues de Lavallade, London, UK; Roberta Di Blasi, Rome, Italy and Creteil, France; Peter Donnelly, Nijmegen, Netherlands; Lubos Drgona, Bratislava, Slovakia; Rafael Duarte, Madrid, Spain; Sigrun Einarsdottir, Gothenburg, Sweden; Hermann Einsele, Würzburg, Germany; Giuseppe Gallo, Verona, Italy; Hildegard Greinix, Graz, Austria; Raoul Herbrecht, Strasbourg, France; Joshua Hill, Seattle, US; Petr Hubacek, Prague, Czech Republic; Csaba Kassa, Budapest, Hungary; Galina Klyasova, Moscow, Russia; Sylwia Koltan, Bydgoszcz, Poland; Thomas Lehrnbecher, Frankfurt, Germany; Per Ljungman, Stockholm, Sweden; Olivier Lortholary, Paris, France; Jens Lundgren, Copenhagen, Denmark; Johan Maertens, Leuven, Belgium; Rodrigo Martino, Barcelona, Spain; Georg Maschmeyer, Potsdam, Germany; Sibylle Mellinghoff, Cologne, Germany; Malgorzata Mikulska, Genoa, Italy; David Navarro, Valencia, Spain; Anna Maria Nosari, Milan, Italy; Livio Pagano, Rome, Italy; Karlis Paukssen, Uppsala, Sweden; Olaf Penack, Berlin, Germany; Zdenek Racil, Brno, Czech Republic; Christine Robin, Créteil, France; Emmanuel Roilides, Thessaloniki, Greece; Montserrat Rovira, Barcelona, Spain; Monica Slavin, Melbourne, Australia; Jan Styczynski, Bydgoszcz, Poland; Anne Thiebaut, Grenoble, France; Claudio Viscoli, Genoa, Italy; Katherine Ward, London, UK; Christine Wenneras, Gothenburg, Sweden. Representatives of pharmaceutical companies supporting ECIL 7: Laurence Dubel, Astellas; Liz Mills, Clinigen; Markus Rupp, MSD; Sonia Sanchez, Gilead; Stefan Zeitler, Basilea.

\section{Compliance with ethical standards}

Conflict of interest GM accepted honoraria for lectures from Gilead, Pfizer, Boehringer Ingelheim, Celgene, Bristol-Myers Squibb, MerckSerono, Novartis, honorarium for advice from Gilead and a travel grant from Bristol-Myers Squibb. JAM accepted grants, personal fees and nonfinancial support from MSD, Astellas, Pfizer and Gilead, personal fees and nonfinancial support from Basilea and F2G and personal fees from Scynexis. The other authors declare that they have no conflict of interest. 
Publisher's note: Springer Nature remains neutral with regard to jurisdictional claims in published maps and institutional affiliations.

Open Access This article is licensed under a Creative Commons Attribution 4.0 International License, which permits use, sharing, adaptation, distribution and reproduction in any medium or format, as long as you give appropriate credit to the original author(s) and the source, provide a link to the Creative Commons license, and indicate if changes were made. The images or other third party material in this article are included in the article's Creative Commons license, unless indicated otherwise in a credit line to the material. If material is not included in the article's Creative Commons license and your intended use is not permitted by statutory regulation or exceeds the permitted use, you will need to obtain permission directly from the copyright holder. To view a copy of this license, visit http://creativecommons. org/licenses/by/4.0/

\section{References}

1. Blincyto summary of product characteristics. https://www.ema. europa.eu/documents/product-information/blincyto-epar-productinformation_en.pdf. Accessed 24 December 2018.

2. Goebeler ME, Bargou R. Blinatumomab: a CD19/CD3 bispecific $\mathrm{T}$ cell engager (BiTE) with unique anti-tumor efficacy. Leuk Lymphoma. 2016;57:1021-32.

3. Wang K, Wei G, Liu D. CD19: a biomarker for B cell development, lymphoma diagnosis and therapy. Exp Hematol Oncol. 2012;1:36

4. Bargou R, Leo E, Zugmaier G, Klinger M, Goebeler M, Knop S, et al. Tumor regression in cancer patients by very low doses of a T cell-engaging antibody. Science. 2008;321:974-7.

5. Nägele V, Kratzer A, Zugmaier G, Holland C, Hijazi Y, Topp MS, et al. Changes in clinical laboratory parameters and pharmacodynamic markers in response to blinatumomab treatment of patients with relapsed/refractory ALL. Exp Hematol Oncol. 2017;6:14.

6. Zugmaier G, Topp MS, Alekar S, Viardot A, Horst HA, Neumann $S$, et al. Long-term follow-up of serum immunoglobulin levels in blinatumomab-treated patients with minimal residual disease-positive B-precursor acute lymphoblastic leukemia. Blood Cancer J. 2014;4:244.

7. Bhoj VG, Arhontoulis D, Wertheim G, Capobianchi J, Callahan CA, Ellebrecht CT, et al. Persistence of long-lived plasma cells and humoral immunity in individuals responding to CD19directed CAR T-cell therapy. Blood. 2016;128:360-70.

8. Kantarjian H, Stein A, Gökbuget N, Fielding AK, Schuh AC, Ribera JM, et al. Blinatumomab versus chemotherapy for advanced acute lymphoblastic leukemia. $\mathrm{N}$ Engl J Med. 2017;376:836-47.

9. Topp MS, Gökbuget N, Stein AS, Zugmaier G, O'Brien S, Bargou RC, et al. Safety and activity of blinatumomab for adult patients with relapsed or refractory B-precursor acute lymphoblastic leukaemia: a multicentre, single arm, phase 2 study. Lancet Oncol. 2015;16:57-66.

10. Chan TSY, Kwong YL. Systemic trichosporonosis mimicking disseminated varicella zoster viral infection during blinatumomab therapy. Ann Hematol. 2018;97:371-3.

11. Wilke AC, Gökbuget N. Clinical applications and safety evaluation of the new CD19 specific T-cell engager antibody construct blinatumomab. Expert Opin Drug Saf. 2017;16: 1191-202.

12. DasGupta RK, Marini BL, Rudoni J, Perissinotti AJ. A review of CD19-targeted immunotherapies for relapsed or refractory acute lymphoblastic leukemia. J Oncol Pharm Pract. 2018;24:453-67.
13. Okeley NM, Miyamoto JB, Zhang X, Sanderson RJ, Benjamin DR, Sievers EL, et al. Intracellular activation of SGN-35, a potent anti-CD30 antibody-drug conjugate. Clin Cancer Res. 2010;16:888-97.

14. Adcetris summary of product characteristics. http://www.ema. europa.eu/docs/en_GB/document_library/EPAR_-_Product_ Information/human/002455/WC500135055.pdf. Accessed 22 November 2017.

15. Chiarle R, Podda A, Prolla G, Gong J, Thorbecke GJ, Inghirami G. CD30 in normal and neoplastic cells. Clin Immunol. 1999;90:157-64.

16. Bekiaris V, Gaspal F, Kim MY, Withers DR, Sweet C, Anderson $\mathrm{G}$, et al. Synergystic OX40 and CD30 signals sustain CD8+T cells during antigenic challenge. Eur J Immunol. 2009;39:2120-5.

17. Muta H, Podack ER. CD30: from basic research to cancer therapy. Immunol Res. 2013;57:151-8.

18. Marín ND, García LF. The role of CD30 and CD153 (CD30L) in the anti-mycobacterial immune response. Tuberculosis. 2017;102:8-15.

19. Younes A, Gopal AK, Smith SE, Ansell SM, Rosenblatt JD, Savage KJ, et al. Results of a pivotal phase II study of brentuximab vedotin for patients with relapsed or refractory Hodgkin's lymphoma. J Clin Oncol. 2012;30:2183-9.

20. Pro B, Advani R, Brice P, Bartlett NL, Rosenblatt JD, Illidge T, et al. Brentuximab vedotin (SGN-35) in patients with relapsed or refractory systemic anaplastic large-cell lymphoma: results of a phase II study. J Clin Oncol. 2012;30:2190-6.

21. Moskowitz CH, Nademanee A, Masszi T, Agura E, Holowiecki J, Abidi MH, et al. Brentuximab vedotin as consolidation therapy after autologous stem-cell transplantation in patients with Hodgkin's lymphoma at risk of relapse or progression (AETHERA): a randomised, double-blind, placebo-controlled, phase 3 trial. Lancet. 2015;385:1853-62.

22. Connors JM, Jurczak W, Straus DJ, Ansell SM, Kim WS, Gallamini A, et al. Brentuximab vedotin with chemotherapy for stage III or IV Hodgkin's lymphoma. N Engl J Med. 2018;378:331-44.

23. Prince HM, Kim YH, Horwitz SM, Dummer R, Scarisbrick J, Quaglino $\mathrm{P}$, et al. Brentuximab vedotin or physician's choice in CD30-positive cutaneous T-cell lymphoma (ALCANZA): an international, open-label, randomised, phase 3, multicentre trial. Lancet. 2017;390:555-66.

24. O'Connor OA, Lue JK, Sawas A, Amengual JE, Deng C, Kalac M, et al. Brentuximab vedotin plus bendamustine in relapsed or refractory Hodgkin's lymphoma: an international multicenter, single-arm, phase 1-2 trial. Lancet Oncol. 2018;19:257-66.

25. Sabet Y, Ramirez S, Rosell Cespedes E, Rensoli Velasquez M, Porres-Muñoz M, Gaur S, et al. Severe acute pulmonary toxicity associated with brentuximab in a patient with refractory Hodgkin's lymphoma. Case Rep Pulmonol. 2016;2016:2359437.

26. Ogura M, Tobinai K, Hatake K, Ishizawa K, Uike N, Uchida T, et al. Phase I/II study of brentuximab vedotin in Japanese patients with relapsed or refractory CD30-positive Hodgkin's lymphoma or systemic anaplastic large-cell lymphoma. Cancer Sci. 2014;105:840-6.

27. Bassetti M, Pecori D, Righi E, Brillo F, Cadeo B, Venturini S, et al. HSV-1 cutaneous infection in a patient with Hodgkin's lymphoma treated with brentuximab vedotin. J Chemother. 2013;25:381-2.

28. Gopal AK, Ramchandren R, O'Connor OA, Berryman RB, Advani RH, Chen R, et al. Safety and efficacy of brentuximab vedotin for Hodgkin lymphoma recurring after allogeneic stem cell transplantation. Blood. 2012;120:560-8.

29. Tudesq JJ, Vincent L, Lebrun J, Hicheri Y, Gabellier L, Busetto T, et al. Cytomegalovirus infection with retinitis after brentuximab 
vedotin treatment for CD30+lymphoma. Open Forum Infect Dis. 2017;4:ofx091.

30. US Food and Drug Administration. FDA Drug Safety Communication: new boxed warning and contraindication for Adcetris (brentuximab vedotin), issued on 1/13/2012. https://www.fda.gov/ Drugs/DrugSafety/ucm287668.html. Accessed 6 August 2018.

31. Carson KR, Newsome SD, Kim EJ, Wagner-Johnston ND, von Geldern G, Moskowitz CH, et al. Progressive multifocal leukoencephalopathy associated with brentuximab vedotin therapy: a report of 5 cases from the Southern Network on Adverse Reactions (SONAR) project. Cancer. 2014;120:2464-71.

32. Raisch DW, Rafi JA, Chen C, Bennett CL. Detection of cases of progressive multifocal leukoencephalopathy associated with new biologicals and targeted cancer therapies from the FDA's adverse event reporting system. Expert Opin Drug Saf. 2016;15:1003-11.

33. Garcia-Suarez J, de Miguel D, Krsnik I, Banas H, Arribas I, Burgaleta C. Changes in the natural history of progressive multifocal leukoencephalopathy in HIV-negative lymphoproliferative disorders: impact of novel therapies. Am J Hematol. 2005;80:271-81.

34. Amend KL, Turnbull B, Foskett N, Napalkov P, Kurth T, Seeger J. Incidence of progressive multifocal leukoencephalopathy in patients without HIV. Neurology. 2010;75:1326-32.

35. Maertens J, Cesaro S, Maschmeyer G, Einsele H, Donnelly JP, Alanio A, et al. ECIL guidelines for preventing Pneumocystis jirovecii pneumonia in patients with haematological malignancies and stem cell transplant recipients. J Antimicrob Chemother. 2016;71:2397-404.

36. Sandherr M, Hentrich M, von Lilienfeld-Toal M, Massenkeil G, Neumann S, Penack O, et al. Antiviral prophylaxis in patients with solid tumours and haematological malignancies - update of the guidelines of the Infectious Diseases Working Party (AGIHO) of the German Society for Hematology and Medical Oncology (DGHO). Ann Hematol. 2015;94:1441-50.

37. Calabrese L. A rational approach to PML for the clinician. Cleve Clin J Med. 2011;78(Suppl 2):S38-41.

38. Theurich S, Rothschild SI, Hoffmann M, Fabri M, Sommer A, Garcia-Marquez M, et al. Local tumor treatment in combination with systemic ipilimumab immunotherapy prolongs overall survival in patients with advanced malignant melanoma. Cancer Immunol Res. 2016;4:744-54.

39. Ansell SM, Lesokhin AM, Borrello I, Halwani A, Scott EC, Gutierrez M, et al. PD-1 blockade with nivolumab in relapsed or refractory Hodgkin's lymphoma. N Engl J Med. 2015; 372:311-9.

40. Ferris RL, Blumenschein G Jr, Fayette J, Guigay J, Colevas AD, Licitra L, et al. Nivolumab for recurrent squamous-cell carcinoma of the head and neck. N Engl J Med. 2016;375:1856-67.

41. Hodi FS, O'Day SJ, McDermott DF, Weber RW, Sosman JA, Haanen JB, et al. Improved survival with ipilimumab in patients with metastatic melanoma. N Engl J Med. 2010;363:711-23.

42. Ribas A, Puzanov I, Dummer R, Schadendorf D, Hamid O, Robert C, et al. Pembrolizumab versus investigator-choice chemotherapy for ipilimumab-refractory melanoma (KEYNOTE002): a randomised, controlled, phase 2 trial. Lancet Oncol. 2015;16:908-18.

43. Borghaei H, Paz-Ares L, Horn L, Spigel DR, Steins M, Ready $\mathrm{NE}$, et al. Nivolumab versus docetaxel in advanced nonsquamous non-small-cell lung cancer. $N$ Engl $J$ Med. 2015;373:1627-39.

44. Gandhi L, Rodríguez-Abreu D, Gadgeel S, Esteban E, Felip E, De Angelis F. et al. Pembrolizumab plus chemotherapy in metastatic non-small-cell lung cancer. N Engl J Med. 2018; 378:2078-92.

45. Motzer RJ, Rini BI, McDermott DF, Redman BG, Kuzel TM, Harrison MR, et al. Nivolumab for metastatic renal cell carcinoma: results of a randomized phase II trial. J Clin Oncol. 2015;33:1430-7.

46. Motzer RJ, Escudier B, McDermott DF, George S, Hammers HJ, Srinivas $\mathrm{S}$, et al. Nivolumab versus everolimus in advanced renal-cell carcinoma. N Engl J Med. 2015;373:1803-13.

47. Soiffer RJ, Davids MS, Chen YB. Tyrosine kinase inhibitors and immune checkpoint blockade in allogeneic hematopoietic cell transplantation. Blood. 2018;131:1073-80.

48. Merryman RW, Armand P, Wright KT, Rodig SJ. Checkpoint blockade in Hodgkin and non-Hodgkin lymphoma. Blood Adv. 2017;1:2643-54.

49. Larkin J, Hodi FS, Wolchok JD. Combined nivolumab and ipilimumab or monotherapy in untreated melanoma. N Engl J Med. 2015;373:1270-1.

50. Robert C, Thomas L, Bondarenko I, O'Day S, Weber J, Garbe C, et al. Ipilimumab plus dacarbazine for previously untreated metastatic melanoma. N Engl J Med. 2011;364:2517-26.

51. Keir ME, Butte MJ, Freeman GJ, Sharpe AH. PD-1 and its ligands in tolerance and immunity. Ann Rev Immunol. 2008; 26:677-704.

52. Jin HT, Ahmed R, Okazaki T. Role of PD-1 in regulating T-cell immunity. Curr Top Microbiol Immunol. 2011;350:17-37.

53. Ahmadzadeh M, Johnson LA, Heemskerk B, Wunderlich JR, Dudley ME, White DE, et al. Tumor antigen-specific CD8 $\mathrm{T}$ cells infiltrating the tumor express high levels of PD-1 and are functionally impaired. Blood. 2009;114:1537-44.

54. Chemnitz JM, Eggle D, Driesen J, Classen S, Riley JL, DebeyPascher S, et al. RNA fingerprints provide direct evidence for the inhibitory role of TGFbeta and PD-1 on CD4+T cells in Hodgkin lymphoma. Blood. 2007;110:3226-33.

55. Korman AJ, Peggs KS, Allison JP. Checkpoint blockade in cancer immunotherapy. Adv Immunol. 2006;90:297-339.

56. Taube JM, Klein A, Brahmer JR, Xu H, Pan X, Kim JH, et al. Association of PD-1, PD-1 ligands, and other features of the tumor immune microenvironment with response to anti-PD-1 therapy. Clin Cancer Res. 2014;20:5064-74.

57. Thompson RH, Dong H, Lohse CM, Leibovich BC, Blute ML, Cheville JC, et al. PD-1 is expressed by tumor-infiltrating immune cells and is associated with poor outcome for patients with renal cell carcinoma. Clin Cancer Res. 2007;13:1757-61.

58. Zhang Y, Huang S, Gong D, Qin Y, Shen Q. Programmed death1 upregulation is correlated with dysfunction of tumor-infiltrating CD8+T lymphocytes in human non-small cell lung cancer. Cell Mol Immunol. 2010;7:389-95.

59. Michot JM, Bigenwald C, Champiat S, Collins M, Carbonnel F, Postel-Vinay $S$, et al. Immune-related adverse events with immune checkpoint blockade: a comprehensive review. Eur J Cancer. 2016;54:139-48.

60. Brahmer JR, Tykodi SS, Chow LQ, Hwu WJ, Topalian SL, Hwu $\mathrm{P}$, et al. Safety and activity of anti-PD-L1 antibody in patients with advanced cancer. N Engl J Med. 2012;366:2455-65.

61. Topalian SL, Hodi FS, Brahmer JR, Gettinger SN, Smith DC, McDermott DF, et al. Safety, activity, and immune correlates of anti-PD-1 antibody in cancer. N Engl J Med. 2012;366:2443-54.

62. Akhtari M, Waller EK, Jaye DL, Lawson DH, Ibrahim R, Papadopoulos NE, et al. Neutropenia in a patient treated with ipilimumab (anti-CTLA-4 antibody). J Immunother. 2009;32:322-4.

63. Tabchi S, Weng X, Blais N. Severe agranulocytosis in a patient with metastatic non-small-cell lung cancer treated with nivolumab. Lung Cancer. 2016;99:123-6.

64. Redelman-Sidi G, Michielin O, Cervera C, Ribi C, Aguado JM, Fernández-Ruiz M, et al. ESCMID Study Group for Infections in Compromised Hosts (ESGICH) consensus document on the safety of targeted and biological therapies: an infectious diseases perspective-immune checkpoint inhibitors, cell adhesion 
inhibitors, sphingosine 1-phosphate receptor modulators and proteasome inhibitors. Clin Microbiol Infect. 2018;24(Suppl 2): S95-107.

65. Weber JS, Kähler KC, Hauschild A. Management of immunerelated adverse events and kinetics of response with ipilimumab. J Clin Oncol. 2012;30:2691-7.

66. Del Castillo M, Romero FA, Argüello E, Kyi C, Postow MA, Redelman-Sidi G. The spectrum of serious infections among patients receiving immune checkpoint blockade for the treatment of melanoma. Clin Infect Dis. 2016;63:1490-3.

67. Fujita K, Terashima T, Mio T. Anti-PD1 antibody treatment and the development of acute pulmonary tuberculosis. J Thorac Oncol. 2016;11:2238-40.

68. Lázár-Molnár E, Gácser A, Freeman GJ, Almo SC, Nathenson SG, Nosanchuk JD. The PD-1/PD-L costimulatory pathway critically affects host resistance to the pathogenic fungus Histoplasma capsulatum. Proc Natl Acad Sci USA. 2008;105:2658-63.

69. Seo SK, Jeong HY, Park SG, Lee SW, Choi IW, Chen, et al. Blockade of endogenous B7-H1 suppresses antibacterial protection after primary Listeria monocytogenes infection. Immunology. 2008;123:90-9.

70. Rowe JH, Johanns TM, Ertelt JM, Way SS. PDL-1 blockade impedes $\mathrm{T}$ cell expansion and protective immunity primed by attenuated Listeria monocytogenes. J Immunol. 2008;180:7553-7.

71. Spain L, Diem S, Larkin J. Management of toxicities of immune checkpoint inhibitors. Cancer Treat Rev. 2016;44:51-60.

72. Baden LR, Bensinger W, Angarone M, Casper C, Dubberke ER, Freifeld AG, et al. Prevention and treatment of cancer-related infections. J Natl Compr Canc Netw. 2012;10:1412-45.

73. Rieger CT, Liss B, Mellinghoff S, Buchheidt D, Cornely OA, Egerer G, et al. Anti-infective vaccination strategies in patients with hematologic malignancies or solid tumors-Guideline of the Infectious Diseases Working Party (AGIHO) of the German Society of Hematology and Medical Oncology (DGHO). Ann Oncol. 2018;29:1354-65.

74. Dubin K, Callahan MK, Ren B, Khanin R, Viale A, Ling L, et al. Intestinal microbiome analyses identify melanoma patients at risk for checkpoint-blockade-induced colitis. Nat Commun. 2016;7:10391.

75. Chaput N, Lepage P, Coutzac C, Soularue E, Le Roux K, Monot $\mathrm{C}$, et al. Baseline gut microbiota predicts clinical response and colitis in metastatic melanoma patients treated with ipilimumab. Ann Oncol. 2017;28:1368-79.

76. Burger JA, Tedeschi A, Barr PM, Robak T, Owen C, Ghia P, et al. RESONATE-2 Investigators. Ibrutinib as initial therapy for patients with chronic lymphocytic leukemia. N Engl J Med. 2015;373:2425-37.

77. Byrd JC, Brown JR, O'Brien S, Barrientos JC, Kay NE, Reddy $\mathrm{NM}$, et al. RESONATE Investigators. Ibrutinib versus ofatumumab in previously $\mathrm{t}$ reated chronic lymphoid leukemia. $\mathrm{N}$ Engl J Med. 2014;371:213-23.

78. Wang ML, Rule S, Martin P, Goy A, Auer R, Kahl BS, et al. Targeting BTK with ibrutinib in relapsed or refractory mantlecell lymphoma. N Engl J Med. 2013;369:507-16.

79. Noy A, de Vos S, Thieblemont C, Martin P, Flowers CR, Morschhauser $\mathrm{F}$ et al. Targeting Bruton tyrosine kinase with ibrutinib in relapsed/refractory marginal zone lymphoma. Blood. 2017;129:2224-32.

80. Chanan-Khan A, Cramer P, Demirkan F, Fraser G, Silva RS, Grosicki S, et al. Ibrutinib combined with bendamustine and rituximab compared with placebo, bendamustine, and rituximab for previously treated chronic lymphocytic leukaemia or small lymphocytic lymphoma (HELIOS): a randomised, double-blind, phase 3 study. Lancet Oncol. 2016;17:200-11.

81. Dimopoulos MA, Trotman J, Tedeschi A, Matous JV, Macdonald D, Tam C, et al.; iNNOVATE Study Group and the
European Consortium for Waldenström's Macroglobulinemia. Ibrutinib for patients with rituximab-refr actory Waldenström's macroglobulinaemia (iNNOVATE): an open-label substudy of an international, multicentre, phase 3 trial. Lancet Oncol. 2017; 18:241-50.

82. Miklos D, Cutler CS, Arora M, Waller EK, Jagasia M, Pusic I, et al. Ibrutinib for chronic graft-versus-host disease after failure of prior therapy. Blood. 2017;130:2243-50.

83. Satterthwaite AB, Witte ON. The role of Bruton's tyrosine kinase in B-cell development and function: a genetic perspective. Immunol Rev. 2000;175:120-7.

84. Bruton OC. Agammaglobulinemia. Pediatrics. 1952;9:722-8.

85. Weber ANR, Bittner Z, Liu X, Dang TM, Radsak MP, Brunner C. Bruton's Tyrosine Kinase: an emerging key player in innate immunity. Front Immunol. 2017;8:1454.

86. Byrd JC, Furman RR, Coutre SE, Burger JA, Blum KA, Coleman $\mathrm{M}$, et al. Three-year follow-up of treatment-naïve and previously treated patients with CLL and SLL receiving single-agent ibrutinib. Blood. 2015;125:2497-506.

87. Sun C, Tian X, Lee YS, Gunti S, Lipsky A, Herman SE, et al. Partial reconstitution of humoral immunity and fewer infections in patients with chronic lymphocytic leukemia treated with ibrutinib. Blood. 2015;126:2213-9.

88. Messina JA, Maziarz EK, Spec A, Kontoyiannis DP, Perfect JR. Disseminated cryptococcosis with brain involvement in patients with chronic lymphoid malignancies on ibrutinib. Open Forum Infect Dis. 2017;4:ofw261.

89. Okamoto K, Proia LA, Demarais PL. Disseminated cryptococcal disease in a patient with chronic lymphocytic leukemia on ibrutinib. Case Rep Infect Dis. 2016;2016:4642831.

90. Stankowicz M, Banaszynski M, Crawford R. Cryptococcal infections in two patients receiving ibrutinib therapy for chronic lymphocytic leukemia. J Oncol Pharm Pract. 2018:1078155217752078. https://doi.org/10.1177/1078155217752078 [Epub ahead of print].

91. Sun K, Kasparian S, Iyer S, Pingali SR. Cryptococcal meningoencephalitis in patients with mantle cell lymphoma on ibrutinib. Ecancermedicalscience. 2018;12:836.

92. Hammel JA, Roth GM, Ferguson N, Fairley JA. Lower extremity ecchymotic nodules in a patient being treated with ibrutinib for chronic lymphocytic leukemia. JAAD Case Rep. 2017;3:178-9.

93. Wang SY, Ebert T, Jaekel N, Schubert S, Niederwieser D, Al-Ali HK. Miliary tuberculosis after initiation of ibrutinib in chronic lymphocytic leukemia. Ann Hematol. 2015;94:1419-20.

94. Bennett CL, Berger JR, Sartor O, Carson KR, Hrushesky WJ, Georgantopoulos P, et al. Progressive multi-focal leucoencephalopathy among ibrutinib-treated persons with chronic lymphocytic leukaemia. Br J Haematol. 2018;180:301-4.

95. Hsiehchen D, Arasaratnam R, Raj K, Froehlich T, Anderson L. Ibrutinib use complicated by progressive multifocal leukoencephalopathy. Oncology. 2018;95:319-22.

96. Lutz M, Schulze AB, Rebber E, Wiebe S, Zoubi T, Grauer OM, et al. Progressive multifocal leukoencephalopathy after ibrutinib therapy for chronic lymphocytic leukemia. Cancer Res Treat. 2017;49:548-52.

97. Cavallari M, Ciccone M, Falzoni S, Cavazzini F, Formigaro L, Di Virgilio F, et al. Hemophagocytic lymphohistiocytosis after EBV reactivation and ibrutinib treatment in relapsed/refractory chronic lymphocytic leukemia. Leuk Res Rep. 2017;7:11-3.

98. Hammond SP, Chen K, Pandit A, Davids MS, Issa NC, Marty FM. Risk of hepatitis B virus reactivation in patients treated with ibrutinib. Blood. 2018;131:1987-9.

99. Herishanu Y, Katchman H, Polliack A. Severe hepatitis B virus reactivation related to ibrutinib monotherapy. Ann Hematol. 2017;96:689-90.

100. Ahn IE, Jerussi T, Farooqui M, Tian X, Wiestner A, GeaBanacloche J. Atypical Pneumocystis jirovecii pneumonia in 
previously untreated patients with CLL on single-agent ibrutinib. Blood. 2016;128:1940-3.

101. Lee R, Nayernama A, Jones SC, Wroblewski T, Waldron PE. Ibrutinib-associated Pneumocystis jirovecii pneumonia. Am J Hematol. 2017;92:E646-8.

102. Ghez D, Calleja A, Protin C, Baron M, Ledoux MP, Damaj G, et al.; French Innovative Leukemia Organization (FILO) CLL group. Early-onset invasive aspergillosis and other fungal infections in patients treated with ibrutinib. Blood. 2018;131:1955-9.

103. Varughese T, Taur Y, Cohen N, Palomba ML, Seo SK, Hohl TM, et al. Serious infections in patients receiving ibrutinib for treatment of lymphoid malignancies. Clin Infect Dis. 2018;67:687-92.

104. Lionakis MS, Dunleavy K, Roschewski M, Widemann BC, Butman JA, Schmitz R, et al. Inhibition of B cell receptor signaling by ibrutinib in primary CNS lymphoma. Cancer Cell. 2017;31:833-43.

105. Grommes C, Younes A. Ibrutinib in PCNSL: the curios cases of clinical responses and aspergillosis. Cancer Cell. 2017;31:731-3.

106. Chamilos G, Lionakis MS, Kontoyiannis DP. Call for action: invasive fungal infections associated with ibrutinib and other small molecule kinase inhibitors targeting immune signaling pathways. Clin Infect Dis. 2018;66:140-8.

107. de Zwart L, Snoeys J, De Jong J, Sukbuntherng J, Mannaert E, Monshouwer M. Ibrutinib dosing strategies based on interaction potential of CYP3A4 perpetrators using physiologically based pharmacokinetic modeling. Clin Pharmacol Ther. 2016;100:548-57.

108. Randhawa JK, Ferrajoli A. A review of supportive care and recommended preventive approaches for patients with chronic lymphocytic leukemia. Expert Rev Hematol. 2016;9:235-44.

109. Andrick B, Alwhaibi A, DeRemer DL, Quershi S, Khan R, Bryan LJ, et al. Lack of adequate pneumococcal vaccination response in chronic lymphocytic leukaemia patients receiving ibrutinib. Br J Haematol. 2018;182:712-4.

110. Douglas AP, Trubiano JA, Barr I, Leung V, Slavin MA, Tam CS. Ibrutinib may impair serological responses to influenza vaccination. Haematologica. 2017;102:e397-9.

111. Mato AR, Islam P, Daniel C, Strelec L, Kaye AH, Brooks S, et al. Ibrutinib-induced pneumonitis in patients with chronic lymphocytic leukemia. Blood. 2016;127:1064-7.

112. Vanhaesebroeck B, Stephens L, Hawkins P. PI3K signalling: the path to discovery and understanding. Nat Rev Mol Cell Biol. 2012;13:195-203.

113. Vanhaesebroeck B, Guillermet-Guibert J, Graupera M, Bilanges B. The emerging mechanisms of isoform-specific PI3K signalling. Nat Rev Mol Cell Biol. 2010;11:32941.

114. Durand CA, Hartvigsen K, Fogelstrand L, Kim S, Iritani S, Vanhaesebroeck B, et al. Phosphoinositide 3-kinase p110 delta regulates natural antibody production, marginal zone and B-1 B cell function, and autoantibody responses. J Immunol. 2009;183:5673-84.

115. Bilancio A, Okkenhaug K, Camps M, Emery JL, Ruckle T, Rommel C, et al. Key role of the p110delta isoform of PI3K in B-cell antigen and IL-4 receptor signaling: comparative analysis of genetic and pharmacologic interference with p110delta function in B cells. Blood. 2006;107:642-50.

116. Lannutti BJ, Meadows SA, Herman SE, Kashishian A, Steiner B, Johnson AJ, et al. CAL-101, a p110delta selective phosphatidylinositol-3-kinase inhibitor for the treatment of B-cell malignancies, inhibits PI3K signaling and cellular viability. Blood. 2011;117:591-4.

117. Hoellenriegel J, Meadows SA, Sivina M, Wierda WG, Kantarjian $\mathrm{H}$, Keating MJ, et al. The phosphoinositide 3'-kinase delta inhibitor, CAL-101, inhibits B-cell receptor signaling and chemokine networks in chronic lymphocytic leukemia. Blood. 2011;118:3603-12.

118. Herman SE, Lapalombella R, Gordon AL, Ramanunni A, Blum $\mathrm{KA}$, Jones J, et al. The role of phosphatidylinositol 3-kinase- $\delta$ in the immunomodulatory effects of lenalidomide in chronic lymphocytic leukemia. Blood. 2011;117:4323-7.

119. Alflen A, Stadler N, Aranda Lopez P, Teschner D, Theobald M, Heß G, et al. Idelalisib impairs TREM-1 mediated neutrophil inflammatory responses. Sci Rep. 2018;8:5558.

120. Flinn IW, Kahl BS, Leonard JP, Furman RR, Brown JR, Byrd JC, et al. Idelalisib, a selective inhibitor of phosphatidylinositol 3kinase-d, as therapy for previously treated indolent nonHodgkin lymphoma. Blood. 2014;123:3406-13.

121. Gopal AK, Kahl BS, de Vos S, Wagner-Johnston ND, Schuster SJ, Jurczak WJ, et al. PI3Kd inhibition by idelalisib in patients with relapsed indolent lymphoma. N Engl J Med. 2014; 370:1008-18.

122. Kahl BS, Spurgeon SE, Furman RR, Flinn IW, Coutre SE, Brown JR, et al. A phase 1 study of the PI3Kd inhibitor idelalisib in patients with relapsed/refractory mantle cell lymphoma (MCL). Blood. 2014;123:3398-405.

123. Brown JR, Byrd JC, Coutre SE, Benson DM, Flinn IW, WagnerJohnston ND, et al. Idelalisib, an inhibitor of phosphatidylinositol 3-kinase $\mathrm{p} 110 \delta$, for relapsed/refractory chronic lymphocytic leukemia. Blood. 2014;123:3390-7.

124. Furman RR, Sharman JP, Coutre SE, Cheson BD, Pagel JM, Hillmen $\mathrm{P}$, et al. Idelalisib and rituximab in relapsed chronic lymphocytic leukemia. N Engl J Med. 2014;370:997-1007.

125. O'Brien SM, Lamanna N, Kipps TJ, Flinn I, Zelenetz AD, Burger JA, et al. A phase 2 study of idelalisib plus rituximab in treatment-naïve older patients with chronic lymphocytic leukemia. Blood. 2015;126:2686-94.

126. Jones JA, Robak T, Brown JR, Awan FT, Badoux X, Coutre S, et al. Efficacy and safety of idelalisib in combination with ofatumumab for previously treated chronic lymphocytic leukemia: an open-label, randomised phase 3 trial. Lancet Haematol. 2017;4:e114-26.

127. Zelenetz AD, Barrientos JC, Brown JR, Coiffier B, Delgado J, Egyed M, et al. Idelalisib or placebo in combination with bendamustine and rituximab in patients with relapsed or refractory chronic lymphocytic leukaemia: interim results from a phase 3, randomised, double-blind, placebo-controlled trial. Lancet Oncol. 2017;18:297-311.

128. Barr PM, Saylors GB, Spurgeon SE, Cheson BD, Greenwald DR, O'Brien SM, et al. Phase 2 study of idelalisib and entospletinib: pneumonitis limits combination therapy in relapsed refractory CLL and NHL. Blood. 2016;127: 2411-5.

129. Smith SM, Pitcher BN, Jung SH, Bartlett NL, Wagner-Johnston N, Park SI, et al. Safety and tolerability of idelalisib, lenalidomide and rituximab in relapsed and refractory lymphoma: the Alliance for Clinical Trials in Oncology A051201 and A051202 phase 1 trials. Lancet Haematol. 2017;4:e176-82.

130. Cheah CY, Nastoupil LJ, Neelapu SS, Forbes SG, Oki Y, Fowler $\mathrm{NH}$. Lenalidomide, idelalisib, and rituximab are unacceptably toxic in patients with relapsed/refractory indolent lymphoma. Blood. 2015;125:3357-9.

131. Sehn LH, Hallek M, Jurczak W, Brown JR, Barr PM, Catalano J, et al. A retrospective analysis of Pneumocystis jirovecii pneumonia infection in patients receiving idelalisib in clinical trials. Blood. 2016;128:3705.

132. Reinwald M, Silva JT, Mueller NJ, Fortún J, Garzoni C, de Fijter JW, et al. ESCMID Study group for Infections in Compromised Hosts (ESGICH) Consensus document on the safety of targeted and biological therapies: an infectious diseases perspective (Intracellular signaling pathways: tyrosine kinase and mTOR inhibitors). Clin Microbiol Infect. 2018;24:S53-70. Suppl 2

133. Zydelig Prescribing Information. http://www.gilead.com/ $\sim /$ media/Files/pdfs/medicines/oncology/zydelig/zydelig_pi.pdf. Accessed 5 August 2018. 
134. Cheah CY, Fowler NH. Idelalisib in the management of lymphoma. Blood. 2016;128:331-6.

135. https://www.ema.europa.eu/documents/variation-report/zydeligh-c-003843-a20-1439-0023-epar-assessment-report-article-20_ en.pdf

136. Lane AA, Chabner BA. Histone deacetylase inhibitors in cancer therapy. J Clin Oncol. 2009;27:5459-68.

137. Roger T, Lugrin J, Le Roy D, Goy G, Mombelli M, Koessler T, et al. Histone deacetylase inhibitors impair innate immune responses to Toll-like receptor agonists and to infection. Blood. 2011;117:1205-17.

138. Bode KA, Dalpke AH. HDAC inhibitors block innate immunity. Blood. 2011;117:1202-3.

139. Coiffier B, Pro B, Prince HM, Foss F, Sokol L, Greenwood M, et al. Results from a pivotal, open-label, phase II study of romidepsin in relapsed or refractory peripheral T-cell lymphoma after prior systemic therapy. J Clin Oncol. 2012;30:631-6.

140. Whittaker SJ, Demierre MF, Kim EJ, Rook AH, Lerner A, Duvic $\mathrm{M}$, et al. Final results from a multicenter, international, pivotal study of romidepsin in refractory cutaneous T-cell lymphoma. J Clin Oncol. 2010;28:4485-91

141. Foss F, Coiffier B, Horwitz S, Pro B, Prince HM, et al. Tolerability to romidepsin in patients with relapsed/refractory T-cell lymphoma. Biomark Res. 2014;2:16.

142. Iyer SP, Foss FF. Romidepsin for the treatment of peripheral Tcell lymphoma. Oncologist. 2015;20:1084-91.

143. Klimek VM, Fircanis S, Maslak P, Guernah I, Baum M, Wu N, et al. Tolerability, pharmacodynamics, and pharmacokinetics studies of depsipeptide (romidepsin) in patients with acute myelogenous leukemia or advanced myelodysplastic syndromes. Clin Cancer Res. 2008;14:826-32.

144. Richardson PG, Hungria VT, Yoon SS, Beksac M, Dimopoulos MA, Elghandour A, et al. Panobinostat plus bortezomib and dexamethasone in previously treated multiple myeloma: outcomes by prior treatment. Blood. 2016;127:713-21.

145. Reddy SA. Romidepsin for the treatment of relapsed/refractory cutaneous T-cell lymphoma (mycosis fungoides/Sézary syndrome): use in a community setting. Crit Rev Oncol Hematol. 2016;106:99-107.

146. Younes A, Sureda A, Ben-Yehuda D, Zinzani PL, Ong TC, Prince $\mathrm{HM}$, et al. Panobinostat in patients with relapsed/refractory Hodgkin's lymphoma after autologous stem-cell transplantation: results of a phase II study. J Clin Oncol. 2012;30:2197-203.

147. Budde LE, Zhang MM, Shustov AR, Pagel JM, Gooley TA, Oliveira GR, et al. A phase I study of pulse high-dose vorinostat (V) plus rituximab (R), ifosphamide, carboplatin, and etoposide (ICE) in patients with relapsed lymphoma. $\mathrm{Br} \mathrm{J}$ Haematol. 2013;161:183-91.

148. Burke MJ, Lamba JK, Pounds S, Cao X, Ghodke-Puranik Y, Lindgren BR, et al. A therapeutic trial of decitabine and vorinostat in combination with chemotherapy for relapsed/refractory acute lymphoblastic leukemia. Am J Haematol. 2014;89:889-95.

149. Piekarz RL, Frye R, Turner M, Wright JJ, Allen SL, Kirschbaum $\mathrm{MH}$, et al. Phase II multi-institutional trial of the histone deacetylase inhibitor romidepsin as monotherapy for patients with cutaneous T-cell lymphoma. J Clin Oncol. 2009;27:5410-17.

150. Piekarz RL, Frye R, Prince HM, Kirschbaum MH, Zain J, Allen $\mathrm{SL}$, et al. Phase 2 trial of romidepsin in patients with peripheral T-cell lymphoma. Blood. 2011;117:5827-34.

151. Ghobrial IM, Campigotto F, Murphy TJ, Boswell EN, Banwait $\mathrm{R}$, Azab F, et al. Results of a phase 2 trial of the single-agent histone deacetylase inhibitor panobinostat in patients with relapsed/refractory Waldenström macroglobulinemia. Blood. 2013;121:1296-303.

152. Archin NM, Liberty AL, Kashuba AD, Choudhary SK, Kuruc JD, Crooks AM, et al. Administration of vorinostat disrupts
HIV-1 latency in patients on antiretroviral therapy. Nature. 2012;487:482-5

153. Tsai P, Wu G, Baker CE, Thayer WO, Spagnuolo RA, Sanchez $\mathrm{R}$, et al. In vivo analysis of the effect of panobinostat on cellassociated HIV RNA and DNA levels and latent HIV infection. Retrovirology. 2016;13:36.

154. Olesen R, Vigano S, Rasmussen TA, Søgaard OS, Ouyang Z, Buzon $\mathrm{M}$, et al. Innate immune activity correlates with CD4 T cell-associated HIV-1 DNA decline during latency-reversing treatment with panobinostat. J Virol. 2015;89:10176-89.

155. Jones RB, O'Connor R, Mueller S, Foley M, Szeto GL, Karel D, et al. Histone deacetylase inhibitors impair the elimination of HIV-infected cells by cytotoxic T-lymphocytes. PLoS Pathog. 2014;10:e1004287.

156. Faivre S, Kroemer G, Raymond E. Current development of mTOR inhibitors as anticancer agents. Nat Rev Drug Discov. 2006;5:671-88.

157. Eiden AM, Zhang S, Gary JM, Simmons JK, Mock BA. Molecular pathways: increased susceptibility to infection is a complication of mTOR inhibitor use in cancer therapy. Clin Cancer Res. 2016;22:277-83.

158. Xu J, Tian D. Hematologic toxicities associated with mTOR inhibitors temsirolimus and everolimus in cancer patients: a systematic review and meta-analysis. Curr Med Res Opin. 2014;30:67-74.

159. Kaymakcalan MD, Je Y, Sonpavde G, Galsky M, Nguyen PL, Heng DY, et al. Risk of infections in renal cell carcinoma (RCC) and non-RCC patients treated with mammalian target of rapamycin inhibitors. Br J Cancer. 2013; 108:2478-84.

160. De Castro N, Xu F, Porcher R, Pavie J, Molina JM, Peraldi MN. Pneumocystis jirovecii pneumonia in renal transplant recipients occurring after discontinuation of prophylaxis: a case-control study. Clin Microbiol Infect. 2010;16:1375-7.

161. Xie X, Jiang Y, Lai X, Xiang S, Shou Z, Chen J. mTOR inhibitor versus mycophenolic acid as the primary immunosuppression regime combined with calcineurin inhibitor for kidney transplant recipients: a meta-analysis. BMC Nephrol. 2015;16:91.

162. Jennings DL, Lange N, Shullo M, Latif F, Restaino S, Topkara $\mathrm{VK}$, et al. Outcomes associated with mammalian target of rapamycin (mTOR) inhibitors in heart transplant recipients: a meta-analysis. Int J Cardiol. 2018;265:71-6.

163. Albiges L, Chamming's F, Duclos B, Stern M, Motzer RJ, Ravaud A, et al. Incidence and management of mTOR inhibitorassociated pneumonitis in patients with metastatic renal cell carcinoma. Ann Oncol. 2012;23:1943-53.

164. Iacovelli R, Palazzo A, Mezi S, Morano F, Naso G, Cortesi E. Incidence and risk of pulmonary toxicity in patients treated with mTOR inhibitors for malignancy. A meta-analysis of published trials. Acta Oncol. 2012;51:873-9.

165. Willemsen AE, van Herpen CM. mTOR inhibitor-related pulmonary toxicity; incidence even higher. Acta Oncol. 2013; 52:1234.

166. Tefferi A. Ruxolitinib targets DCs: for better or worse? Blood. 2013;122:1096-7.

167. Heine A, Held SA, Daecke SN, Wallner S, Yajnanarayana SP, Kurts C, et al. The JAK-inhibitor ruxolitinib impairs dendritic cell function in vitro and in vivo. Blood. 2013;122:1192-202.

168. Parampalli Yajnanarayana S, Stübig T, Cornez I, Alchalby H, Schönberg K, Rudolph J, et al. JAK1/2 inhibition impairs T cell function in vitro and in patients with myeloproliferative neoplasms. Br J Haematol. 2015;169:824-33.

169. Keohane C, Kordasti S, Seidl T, Perez Abellan P, Thomas NS, Harrison CN, et al. JAK inhibition induces silencing of T Helper cytokine secretion and a profound reduction in T regulatory cells. Br J Haematol. 2015;171:60-73. 
170. Massa M, Rosti V, Campanelli R, Fois G, Barosi G. Rapid and long-lasting decrease of T-regulatory cells in patients with myelofibrosis treated with ruxolitinib. Leukemia. 2014;28: 449-51.

171. Villarino AV, Kanno Y, Ferdinand JR, O'Shea JJ. Mechanisms of JAK/STAT signaling in immunity and disease. J Immunol. 2015;194:21-7.

172. Schönberg K, Rudolph J, Vonnahme M, Parampalli Yajnanarayana S, Cornez I, Hejazi M, et al. JAK Inhibition impairs NK cell function in myeloproliferative neoplasms. Cancer Res. 2015;75:2187-99.

173. Cervantes F, Dupriez B, Pereira A, Passamonti F, Reilly JT, Morra E, et al. New prognostic scoring system for primary myelofibrosis based on a study of the International Working Group for Myelofibrosis Research and Treatment. Blood. 2009;113: 2895-901.

174. Passamonti F, Cervantes F, Vannucchi AM, Morra E, Rumi E, Pereira A, et al. A dynamic prognostic model to predict survival in primary myelofibrosis: a study by the IWG-MRT (International Working Group for Myeloproliferative Neoplasms Research and Treatment). Blood. 2010;115:1703-8.

175. Verstovsek S, Mesa RA, Gotlib J, Levy RS, Gupta V, DiPersio JF, et al. Efficacy, safety, and survival with ruxolitinib in patients with myelofibrosis: results of a median 3-year follow-up of COMFORT-I. Haematologica. 2015;100:479-88.

176. Verstovsek S, Mesa RA, Gotlib J, Gupta V, DiPersio JF, Catalano JV, et al. Long-term treatment with ruxolitinib for patients with myelofibrosis: 5-year update from the randomized, doubleblind, placebo-controlled, phase 3 COMFORT-I trial. J Hematol Oncol. 2017;10:55.

177. Harrison C, Kiladjian JJ, Al-Ali HK, Gisslinger H, Waltzman $\mathrm{R}$, Stalbovskaya V, et al. JAK Inhibition with ruxolitinib versus best available therapy for myelofibrosis. N Engl J Med. 2012;366:787-98.

178. Harrison CN, Vannucchi AM, Kiladjian JJ, Al-Ali HK, Gisslinger $\mathrm{H}$, Knoops $\mathrm{L}$, et al. Long-term findings from COMFORT-II, a phase 3 study of ruxolitinib vs best available therapy for myelofibrosis. Leukemia. 2016;30:1701-7.

179. Mead AJ, Milojkovic D, Knapper S, Garg M, Chacko J, Farquharson $\mathrm{M}$, et al. Response to ruxolitinib in patients with intermediate-1-, intermediate-2-, and high-risk myelofibrosis: results of the UK ROBUST Trial. Br J Haematol. 2015;170:29-39.

180. Al-Ali HK, Griesshammer M, le Coutre P, Waller CF, Liberati AM, Schafhausen P, et al. Safety and efficacy of ruxolitinib in an open label, multicenter, single-arm phase $3 \mathrm{~b}$ expanded-access study in patients with myelofibrosis: a snapshot of 1144 patients in the JUMP trial. Haematologica. 2016;101:1065-73.

181. Vannucchi AM, Kiladjian JJ, Griesshammer M, Masszi T, Durrant S, Passamonti F, et al. Ruxolitinib versus standard therapy for the treatment of polycythemia vera. N Engl J Med. 2015;372:426-35.

182. Passamonti F, Griesshammer M, Palandri F, Egyed M, Benevolo $\mathrm{G}$, Devos $\mathrm{T}$, et al. Ruxolitinib for the treatment of inadequately controlled polycythaemia vera without splenomegaly (RESPONSE-2): a randomised, open-label, phase $3 \mathrm{~b}$ study. Lancet Oncol. 2017;18:88-99.

183. Polverelli N, Breccia M, Benevolo G, Martino B, Tieghi A, Latagliata R, et al. Risk factors for infections in myelofibrosis: role of disease status and treatment. A multicenter study of 507 patients. Am J Hematol. 2017;92:37-41.

184. Palandri F, Polverelli N, Breccia M, Nicolino B, Vitolo U, Alimena G, et al. Safety and efficacy of ruxolitinib in myelofibrosis patients without splenomegaly. Br J Haematol. 2016;174:160-2.

185. Wathes R, Moule S, Milojkovic D. Progressive multifocal leukoencephalopathy associated with ruxolitinib. N Engl J Med. 2013;369:197-8.
186. Goldberg RA, Reichel E, Oshry LJ. Bilateral toxoplasmosis retinitis associated with ruxolitinib. N Engl J Med. 2013; 369:681-3.

187. Von Hofsten J, Johnsson Forsberg M, Zetteberg M. Cytomegalovirus retinitis in a patient who received ruxolitinib. $\mathrm{N}$ Engl $\mathrm{J}$ Med. 2016;374:296-7.

188. Wysham NG, Sullivan DR, Allada G. An opportunistic infection associated with ruxolitinib, a novel janus kinase 1,2 inhibitor. Chest. 2013;143:1478-9.

189. Hirano A, Yamasaki M, Saito N, Iwato K, Daido W, Funaishi K, et al. Pulmonary cryptococcosis in a ruxolitinib-treated patient with primary myelofibrosis. Respir Med Case Rep. 2017;22:87-90.

190. Chen CC, Chen YY, Huang CE. Cryptococcal meningoencephalitis associated with the long-term use of ruxolitinib. Ann Hematol. 2016;95:361-2.

191. Chan JF, Chan TS, Gill H, Lam FY, Trendell-Smith NJ, Sridhar $\mathrm{S}$, et al. Disseminated infections with Talaromyces marneffei in non-AIDS patients given monoclonal antibodies against CD20 and kinase inhibitors. Emerg Infect Dis. 2015;21:1101-6.

192. Lee SC, Feenstra J, Georghiou PR. Pneumocystis jiroveci pneumonitis complicating ruxolitinib therapy. BMJ Case Rep. 2014; pii bcr2014204950. Published online 2014 Jun 2. https:// doi.org/10.1136/bcr-2014-204950.

193. Knödler A, Schmiedel S, Schäfer G, Bokemeyer C, von Amsberg G. Pneumocystis jirovecii pneumonia associated with ruxolitinib therapy in a patient with myelofibrosis. Oncol Res Treat. 2014;37:164-5.

194. Pálmason R, Lindén O, Richter J. Case-report: EBV driven lymphoproliferative disorder associated with ruxolitinib. BMC Hematol. 2015;15:10.

195. Kusano Y, Terui Y, Ueda K, Hatake K. Epstein-Barr virus gastric ulcer associated with ruxolitinib. Ann Hematol. 2016; 95:1741-2.

196. Eyal O, Flaschner M, Ben Yehuda A, Rund D. Varicella-zoster virus meningoencephalitis in a patient treated with ruxolitinib. Am J Hematol. 2017;92:E74-5.

197. Caocci G, Murgia F, Podda L, Solinas A, Atzeni S, La Nasa G. Reactivation of hepatitis B virus infection following ruxolitinib treatment in a patient with myelofibrosis. Leukemia. 2014; 28:225-7.

198. Shen CH, Hwang CE, Chen YY, Chen CC. Hepatitis B virus reactivation associated with ruxolitinib. Ann Hematol. 2014; 93:1075-6.

199. Kirito K, Sakamoto M, Enomoto N. Elevation of the hepatitis B virus DNA during the treatment of Polycythemia Vera with the JAK kinase inhibitor ruxolitinib. Intern Med. 2016;55:1341-4.

200. Perricone G, Vinci M, Pungolino E. Occult hepatitis B infection reactivation after ruxolitinib therapy. Dig Liver Dis. 2017; 49:719.

201. Mallet V, van Bömmel F, Doerig C, Pischke S, Hermine O, Locasciulli A, et al. Management of viral hepatitis in patients undergoing haematopoietic stem cell transplantation: recommendations of the 5th European Conference on Infections in Leukemia (ECIL-5). Lancet Infect Dis. 2016;16:606-17.

202. Reddy KR, Beavers KL, Hammond SP, Lim JK, Falck-Ytter YT. American Gastroenterological Association Institute guideline on the prevention and treatment of hepatitis $\mathrm{B}$ virus reactivation during immunosuppressive drug therapy. Gastroenterology. 2015;148:215-9.

203. European Association for the Study of the Liver. European Association for the Study of the Liver clinical practice guidelines: management of chronic hepatitis $\mathrm{B}$ virus infection. $\mathrm{J}$ Hepatol. 2012;57:167-85.

204. Heine A, Brossart P, Wolf D. Ruxolitinib is a potent immunosuppressive compound: is it time for anti-infective prophylaxis? Blood. 2013;122:3843-4. 
205. Shamil E, Cunningham D, Wong BL, Jani P. Ruxolitinib associated tuberculosis presenting as a neck lump. Case Rep Infect Dis. 2015;2015:284168.

206. Colomba C, Rubino R, Siracusa L, Lalicata F, Trizzino M, Titone L, et al. Disseminated tuberculosis in a patient treated with a JAK2 selective inhibitor: a case report. BMC Res Notes. 2012;5:552.

207. Hopman RK, Lawrence SJ, Oh ST. Disseminated tuberculosis associated with ruxolitinib. Leukemia. 2014;28:1750-1.

208. Palandri F, Polverelli N, Catani L, Vianelli N. Ruxolitinibassociated tuberculosis: a case of successful ruxolitinib rechallenge. Ann Hematol. 2015;94:519-20.

209. Keizer S, Gerritsen R, Jauw Y, Janssen J, Koopman B, Bresser P. Fatal tuberculosis during treatment with ruxolitinib. Ned Tijdschr Geneeskd. 2015;159:A8650.

210. Chen YH, Lee CH, Pei SN. Pulmonary tuberculosis reactivation following ruxolitinib treatment in a patient with primary myelofibrosis. Leuk Lymphoma. 2015;56:1528-9.

211. Branco B, Metsu D, Dutertre M, Marchou B, Delobel P, Recher $\mathrm{C}$, et al. Use of rifampin for treatment of disseminated tuberculosis in a patient with primary myelofibrosis on ruxolitinib. Ann Hematol. 2016;95:1207-9.

212. Abidi MZ, Haque J, Varma P, Olteanu H, Guru Murthy GS, Dhakal B, et al. Reactivation of pulmonary tuberculosis following treatment of myelofibrosis with ruxolitinib. Case Rep Hematol. 2016;2016:2389038.

213. Malkan UY, Haznedaroglu IC. A myelofibrosis case that develops mycobacterial infection after ruxolitinib treatment. Int J Clin Exp Med. 2017;10:7304-7.

214. Polverelli N, Palumbo GA, Binotto G, Abruzzese E, Benevolo $\mathrm{G}$, Bergamaschi $\mathrm{M}$, et al. Epidemiology, outcome, and risk factors for infectious complications in myelofibrosis patients receiving ruxolitinib: A multicenter study on 446 patients. Hematol Oncol. 2018. https://doi.org/10.1002/hon.2509.

215. Lussana F, Cattaneo M, Rambaldi A, Squizzato A. Ruxolitinibassociated infections: a systematic review and meta-analysis. Am J Hematol. 2018;93:339-47.

216. Tefferi A, Pardanani A. Serious adverse events during ruxolitinib treatment discontinuation in patients with myelofibrosis. Mayo Clin Proc. 2011;86:1188-91.

217. Mori Y, Ikeda K, Inomata T, Yoshimoto G, Fujii N, Ago H, et al. Ruxolitinib treatment for GvHD in patients with myelofibrosis. Bone Marrow Transplant. 2016;51:1584-7.
218. Zhu H, Almasan A. Development of venetoclax for therapy of lymphoid malignancies. Drug Des Devel Ther. 2017;11: 685-94.

219. Roberts AW, Davids MS, Pagel JM, Kahl BS, Puvvada SD, Gerecitano JF, et al. Targeting BCL2 with venetoclax in relapsed chronic lymphocytic leukemia. N Engl J Med. 2016;374: $311-22$.

220. Stilgenbauer S, Eichhorst B, Schetelig J, Coutre S, Seymour JF, Munir T, et al. Venetoclax in relapsed or refractory chronic lymphocytic leukaemia with $17 \mathrm{p}$ deletion: a multicentre, openlabel, phase 2 study. Lancet Oncol. 2016;17:768-78.

221. Freise KJ, Jones AK, Eckert D, Mensing S, Wong SL, Humerickhouse RA, et al. Impact of venetoclax esposure on clinical efficacy and safety in patients with relapsed or refractory chronic lymphocytic leukemia. Clin Pharmacokinet. 2017;56:515-23.

222. Leverson JD, Phillips DC, Mitten MJ, Boghaert ER, Diaz D, Tahir SK, et al. Exploiting selective BCL-2 family inhibitors to dissect cell survival dependencies and define improved strategies for cancer therapy. Sci Transl Med. 2015;7:279ra40.

223. Seymour JF, Kipps TJ, Eichhorst B, Hillmen P, D'Rozario J, Assouline $\mathrm{S}$, et al. Venetoclax-rituximab in relapsed or refractory chronic lymphocytic leukemia. $\mathrm{N}$ Engl J Med. 2018;378:1107-20.

224. Lu P, Fleischmann R, Curtis C, Ignatenko S, Clarke SH, Desai $M$, et al. Safety and pharmacodynamics of venetoclax (ABT-199) in a randomized single and multiple ascending dose study in women with systemic lupus erythematosus. Lupus. 2018;27:290-302.

225. Davids MS, Hallek M, Wierda W, Roberts AW, Stilgenbauer S, Jones JA, et al. Comprehensive safety analysis of venetoclax monotherapy for patients with relapsed/refractory chronic lymphocytic leukemia. Clin Cancer Res. 2018;24:4371-9.

226. Seymour JF, Ma S, Brander DM, Choi MY, Barrientos J, Davids MS, et al. Venetoclax plus rituximab in relapsed or refractory chronic lymphocytic leukaemia: a phase 1b study. Lancet Oncol. 2017;18:230-40.

227. Venclexta Prescribing Information. https://www.rxabbvie.com/ pdf/venclexta.pdf. Accessed 5 August 2018.

228. Agarwal SK, DiNardo CD, Potluri J, Dunbar M, Kantarjian HM, Humerickhouse RA, et al. Management of venetoclax - posaconazole interaction in acute myeloid leukemia patients: evaluation of dose adjustments. Clin Ther. 2017;39:359-67. 